BNL-99897-2013-IR

\title{
Irradiation Experiment Conceptual Design Parameters for NBSR Fuel Conversion
}

\author{
N. Brown, J-S. Baek, A. Hanson, A. Cuadra, \\ L-Y. Cheng, D. Diamond
}

March 2013

\author{
Nuclear Science \& Technology Department \\ Brookhaven National Laboratory
}

\author{
U.S. Department of Energy \\ National Institute of Science \& Technology
}

Notice: This manuscript has been authored by employees of Brookhaven Science Associates, LLC under Contract No. DE-AC02-98CH10886 with the U.S. Department of Energy. The publisher by accepting the manuscript for publication acknowledges that the United States Government retains a non-exclusive, paid-up, irrevocable, world-wide license to publish or reproduce the published form of this manuscript, or allow others to do so, for United States Government purposes. 


\section{DISCLAIMER}

This report was prepared as an account of work sponsored by an agency of the United States Government. Neither the United States Government nor any agency thereof, nor any of their employees, nor any of their contractors, subcontractors, or their employees, makes any warranty, express or implied, or assumes any legal liability or responsibility for the accuracy, completeness, or any third party's use or the results of such use of any information, apparatus, product, or process disclosed, or represents that its use would not infringe privately owned rights. Reference herein to any specific commercial product, process, or service by trade name, trademark, manufacturer, or otherwise, does not necessarily constitute or imply its endorsement, recommendation, or favoring by the United States Government or any agency thereof or its contractors or subcontractors. The views and opinions of authors expressed herein do not necessarily state or reflect those of the United States Government or any agency thereof. 
BNL-99897-2013-IR

\section{Irradiation Experiment Conceptual Design Parameters for NBSR Fuel Conversion}

Manuscript Completed:

March 29, 2013

Prepared by:

N. R. Brown, J. S. Baek, A. L. Hanson, A. Cuadra, L-Y. Cheng, and D. J. Diamond

Nuclear Science \& Technology Department

Brookhaven National Laboratory

Upton, NY 11973

Prepared for:

National Institute of Standards and Technology

National Nuclear Security Administration 



\begin{abstract}
It has been proposed to convert the National Institute of Standards and Technology (NIST) research reactor, known as the NBSR, from high-enriched uranium (HEU) fuel to low-enriched uranium (LEU) fuel. The motivation to convert the NBSR to LEU fuel is to reduce the risk of proliferation of special nuclear material. This report is a compilation of relevant information from recent studies related to the proposed conversion using a metal alloy of LEU with 10 w/o molybdenum. The objective is to inform the design of the mini-plate and full-size plate irradiation experiments that are being planned. This report provides relevant dimensions of the fuel elements, and the following parameters at steady state: average and maximum fission rate density and fission density, fuel temperature distribution for the plate with maximum local temperature, and two-dimensional heat flux profiles of fuel plates with high power densities. The latter profiles are given for plates in both the inner and outer core zones and for cores with both fresh and depleted shim arms (reactivity control devices). In addition, a summary of the methodology to obtain these results is presented.
\end{abstract}




\section{Table of Contents}

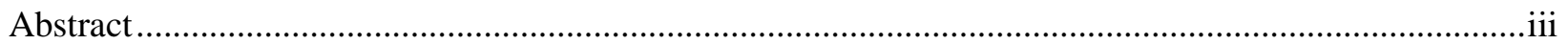

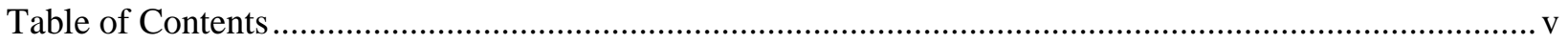

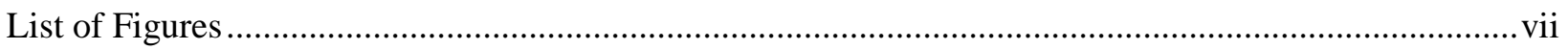

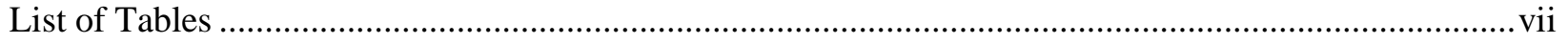

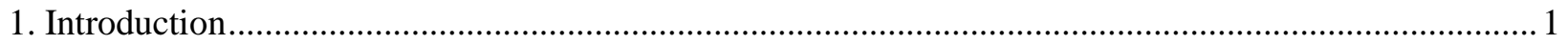

2. Geometry of the Fuel Plates, Fuel Elements, and Reactor Core..................................................... 2

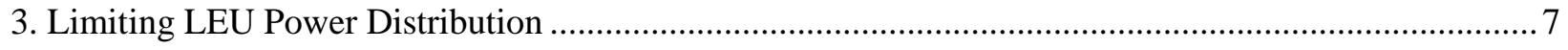

4. Limiting LEU Local Burn-Up and Fission Density ..........................................................21

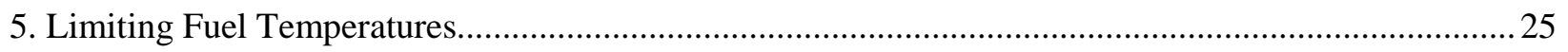

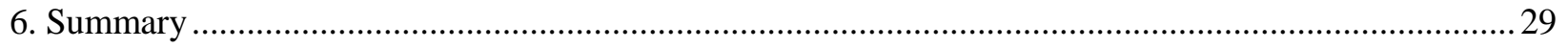

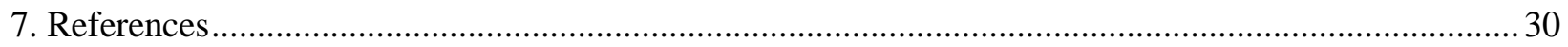




\section{List of Figures}

Figure 1 NBSR Vessel Internals and Reactor Core [1] ...................................................... 3

Figure 2 NBSR Fuel Element ................................................................................ 4

Figure 3 Cross Sectional View of Fuel Element (Dimensions in Inches) .................................. 5

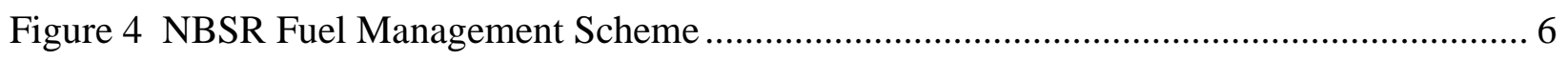

Figure 5 Planar View of the NBSR MCNPX Model ............................................................. 7

Figure 6 NBSR Fuel Element Geometry in the MCNPX Model............................................... 9

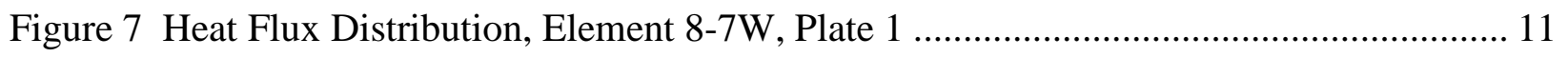

Figure 8 Heat Flux Distribution, Element 8-7W, Plate 17 ..................................................... 12

Figure 9 Heat Flux Distribution, Element 8-3E, Plate 1 ....................................................... 13

Figure 10 Heat Flux Distribution, Element 8-3E, Plate 17.................................................. 14

Figure 11 Heat Flux Distribution, Element 8-7E, Plate 1................................................... 15

Figure 12 Heat Flux Distribution, Element 8-7E, Plate 17.................................................... 16

Figure 13 Heat Flux Distribution, Element 7-2E, Plate 1................................................... 17

Figure 14 Heat Flux Distribution, Element 7-2E, Plate 17................................................... 18

Figure 15 Heat Flux Distribution, Element 8-1E, Plate 1..................................................... 19

Figure 16 Heat Flux Distribution, Element 8-1E, Plate 17.................................................. 20

Figure 17 LEU Cumulative Fission Density at EOC .......................................................... 22

Figure 18 LEU Average Axial Fission Density Distribution at Cycle 8 EOC .......................... 23

Figure 19 LEU Plate-Wise Fission Density at EOC ........................................................... 23

Figure 20 LEU Axial Fission Density Distribution Comparison at Cycle 8 EOC ..................... 25

Figure 21 Hydraulic Flow Channel (shown horizontally) ................................................... 26

Figure 22 Heat Transfer Modeling Simplifications in a Flow Channel................................... 27

Figure 23 Modeling of Power Distribution in the RELAP5 Input Model ................................. 28

Figure 24 Axial LEU Fuel Meat Centerline Temperature Distribution

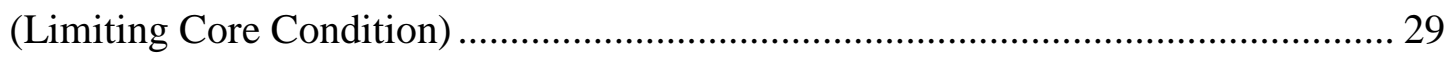

\section{List of Tables}

Table 1 NBSR Fuel Element Data .............................................................................. 4

Table 2 Fraction of Fissions in the LEU NBSR ................................................................ 24

Table 3 Axial Fission Density Distribution at Cycle 8 EOC ................................................. 25

Table 4 Values of the Requested Metrics .......................................................................... 29 


\section{Introduction}

This report is a compilation of results from studies of the conversion of the National Institute of Standards and Technology (NIST) research reactor, known as the NBSR, to low-enriched uranium (LEU) fuel. The objective of this document is to convey the information requested by the plate irradiation experiment design team at Idaho National Laboratory.

Brookhaven National Laboratory (BNL) has an extensive history of collaboration with NIST regarding the NBSR. BNL performed safety analysis in support of the NBSR license renewal application [1]. More recently, BNL has performed the design work and safety analysis for the LEU conversion of the NBSR. Some relevant results of these studies have been recently documented [2-7].

The following information was requested for the NBSR LEU fuel plate irradiation experiment for the most disadvantageous steady state LEU core condition [8]:

1. Nominal geometry and configuration of the fuel plates and fuel assemblies

a. Fuel meat thickness

b. Cladding thickness

c. Absorber thickness

d. Fuel assembly configuration

e. Fuel management scheme

2. Peak local irradiation condition at maximum licensed power

a. Fission density (fission $/ \mathrm{cm}^{3}$ )

b. Fission rate density (fission $/ \mathrm{cm}^{3}$-s)

c. Heat flux distribution

d. Fuel meat and plate surface temperatures

This report is comprised of the following sections:

1. Introduction

2. Geometry of the Fuel Plates, Fuel Elements, and Reactor Core

3. Limiting LEU Power Distribution

4. Limiting LEU Local Burn-Up and Fission Density

5. Limiting Fuel Temperatures

The contents of Section 2 are sourced from References [1-3]. This section presents the requested information regarding the nominal LEU fuel plate and fuel element geometry. The contents of Section 3 are sourced from References [2-5]. Section 3 describes the model geometry, nodalization, fission rate density, and heat flux distribution. The heat flux distribution and fission rate density, as presented within this report, are equivalent. The contents of Section 4 are sourced from References [5-6]. Section 4 describes the average and maximum fission density as 
calculated utilizing local burn-up effect studies. Section 5 is primarily sourced from Reference [3] and Reference [7]. Section 5 presents the thermal hydraulic nodalization and the relevant steady state fuel meat temperature distribution for the LEU NBSR core.

\section{Geometry of the Fuel Plates, Fuel Elements, and Reactor Core}

The NBSR is a high burn-up, $20 \mathrm{MWt}$ reactor. The moderation and cooling is provided by $\mathrm{D}_{2} \mathrm{O}$, which flows upward through the core from two concentric plena just below the lower grid plate. The NBSR is designed with several unique features that enable low-energy and thermal neutrons to stream through eight radial beam tubes and two cold neutron sources. These features include an unfuelled "gap" in the axial center of the fuel elements, which contains only moderator and structural materials. This gap, which acts to minimize contamination of the streaming lowenergy neutrons, is co-located with the beam tubes at the core axial mid-plane. The mid-plane gap is very significant in terms of the NBSR peak local irradiation condition. The axial thermal flux always peaks in the mid-plane gap. Because the axial location of the thermal flux peak is fixed, the fuel that is directly adjacent to the gap experiences both the highest fission rate density and the highest cumulative fission density in the NBSR core.

Another unique feature of the NBSR is the cadmium shim arms (control elements), which traverse the upper-half of the core in a semaphore fashion. During much of a reactor cycle, the shim arms act to suppress the flux in the upper half of the NBSR core. This flux "compression" shifts the peak local irradiation condition to the fuel in the lower half-element that is nearest to the mid-plane gap. A three-dimensional cut-away view of the NBSR vessel internals and reactor core is shown in Figure 1. The mid-plane gap (legend entry 5) and the shim arms (legend entry 2) are both visible in Figure 1. Due to the combined impact of the mid-plane gap and the shim arms, the local cumulative fission density in the NBSR fuel approaches $100 \%$ burn-up of fissile nuclides, primarily ${ }^{235} \mathrm{U}$ and ${ }^{239} \mathrm{Pu}$. 


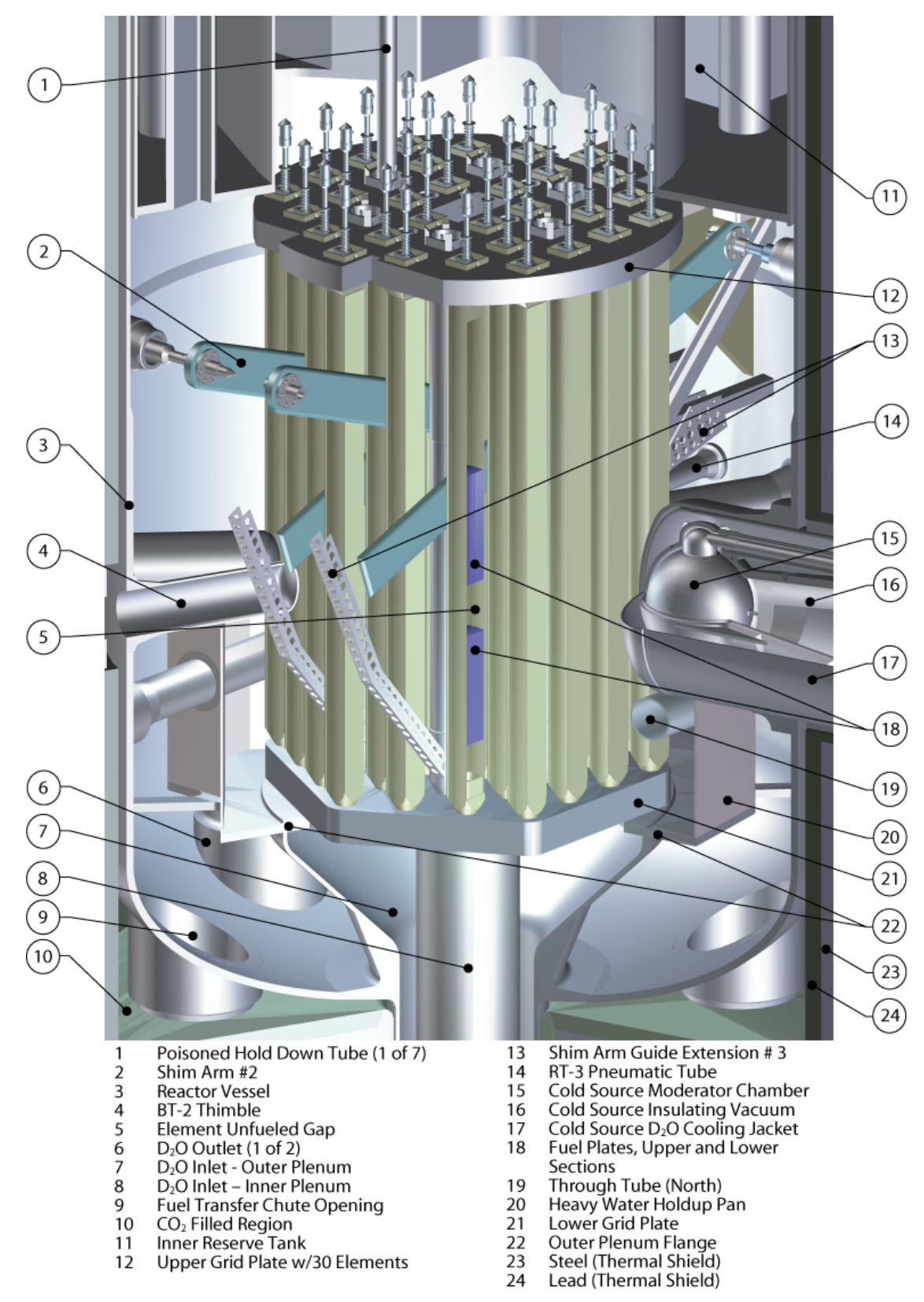

Figure 1 NBSR Vessel Internals and Reactor Core [1]

Presently, the NBSR is fueled with high-enriched uranium (HEU) with a nominal ${ }^{235} \mathrm{U}$ enrichment of 93\% [1]. The fuel is $\mathrm{U}_{3} \mathrm{O}_{8}$ in an aluminum powder dispersion that is clad in aluminum alloy (Alloy 6061). Each fuel element is constructed of 17 plates in each upper and lower half (34 plates per fuel element) and is constructed in the Materials Test Reactor (MTR) curved plate geometry. Each plate is $33.02 \mathrm{~cm}$ (13 in) long with $27.94 \mathrm{~cm}$ (11 in) of fuel and the fuel width is $6.03 \mathrm{~cm}$ (2.373 in). The thickness of fuel meat in each plate is $0.0508 \mathrm{~cm}(0.020 \mathrm{in})$ for HEU fuel, with a volume of $148 \mathrm{~cm}^{3}\left(9.05 \mathrm{in}^{3}\right)$ of fuel per half-element. There is a $17.78 \mathrm{~cm}$ (7 in) gap between the upper and lower fueled regions of the core. In the gap region, the aluminum plates extend one-half inch below and above the fuel so the physical gap is $15.24 \mathrm{~cm}$ 
(6 in). Each HEU fuel element has a mass of $350 \pm 3.4 \mathrm{~g}$ of ${ }^{235} \mathrm{U}$. The aluminum cladding is $0.0381 \mathrm{~cm}(0.015 \mathrm{in})$ thick on each side. Figure 2 shows the lower and upper fuel plates and the physical gap in a fuel element.

The fuel meat for the LEU conversion of the NBSR is proposed as U10Mo (10 wt\% Mo alloyed with $U$ ) metal foils with the same aluminum alloy cladding used in the HEU fuel [2]. The geometrical dimensions of fuel plates in a fuel element are the same for HEU and LEU fuels except for the fuel meat and cladding thickness. Data for the nominal U10Mo fuel design are given in Table 1. The thickness of the LEU fuel foils is $0.0215 \mathrm{~cm}(0.0085 \mathrm{in})$ with a total volume of $62.64 \mathrm{~cm}^{3}\left(3.8 \mathrm{in}^{3}\right)$ per half-element. The engineering specification on fuel foil thickness is $0.0085 \mathrm{in}$. The rolling tolerance of the fuel foils is expected to be $\pm 0.001 \mathrm{in}$, so the fuel thickness is specified as $0.0085 \pm 0.001$ in. The ${ }^{235} \mathrm{U}$ content of each LEU fuel element is $383 \pm 4 \mathrm{~g}$, where the uncertainty is only due to the uncertainty in the molybdenum content of the LEU fuel. The $10 \%$ weight specification for molybdenum has an uncertainty of $\pm 1 \%$. There is also an uncertainty in ${ }^{235} \mathrm{U}$ content due to enrichment uncertainty. The thickness of the aluminum cladding for the LEU fuel is $0.053 \mathrm{~cm}(0.0208 \mathrm{in})$ on each side. There is a 0.00254 $\mathrm{cm}$ (0.001 in) layer of zirconium between the cladding and the fuel to improve fuel behavior under irradiation and this is also taken into account in the modeling.

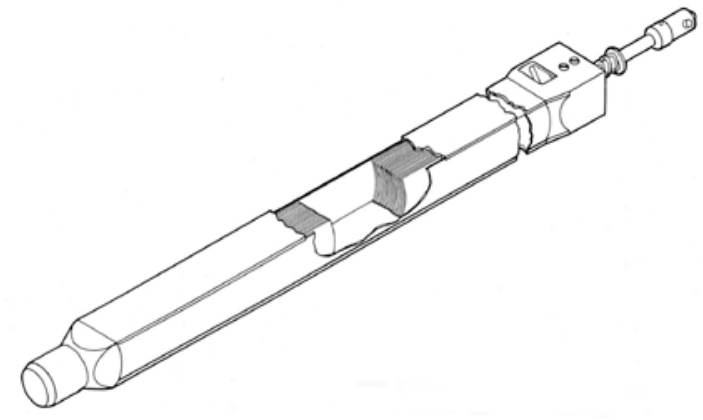

Figure 2 NBSR Fuel Element

Table 1 NBSR Fuel Element Data

\begin{tabular}{|c|c|c|}
\hline Parameter & HEU & LEU \\
\hline${ }^{235}$ U grams & 350 & 383 \\
\hline${ }^{238}$ U grams & 26 & 1556 \\
\hline O grams & 68 & 0 \\
\hline Al grams & 625 & 0 \\
\hline Mo grams & 0 & 215 \\
\hline Total grams & 1069 & 2154 \\
\hline & & \\
\hline Fuel density $\left(\mathrm{g} / \mathrm{cm}^{3}\right)$ & 3.61 & 17.2 \\
\hline Fuel meat thickness $(\mathrm{cm})$ & 0.0508 & 0.0215 \\
\hline Fuel volume, half-element $\left(\mathrm{cm}^{3}\right)$ & 148 & 62.64 \\
\hline
\end{tabular}


Figure 3 shows a cross sectional view of a fuel element. There are a total of 30 fuel elements in the NBSR core. Six fuel elements are located in the inner core (cooled by flow from the inner plenum) and twenty-four elements in the outer core (cooled by flow from the outer plenum). Figure 4 shows the labeling of fuel element positions. The thimble identifiers are bracketed $(<$ $>$ ) and the regulating rod is identified as $\langle\mathrm{RR}>$. In each position fuel elements are identified with two numbers and one letter. The letters are either $\mathrm{E}$ or $\mathrm{W}$ for the east or west side of the core noting that a fuel element always stays in the east side or in the west side of the core. The fuel management scheme of the NBSR dictates that 16 fuel elements stay in the core for eight cycles and 14 fuel elements stay in the core for seven cycles. The first number denotes how many cycles the element will be in the core (either eight or seven) and the second number denotes the cycle in which the fuel element resides. Therefore, at the beginning of a cycle, the 81 and 7-1 fuel elements are unirradiated fuel elements, whereas 8-8 and 7-7 are in their final cycles and will be removed after the cycle is over. After a cycle is finished the 8-8 and 7-7 fuel elements are removed and the 8-7 elements are moved into the 8-8 positions, the 7-6 elements are moved into the 7-7 positions, etc. The process proceeds until unirradiated fuel is placed in the 8-1 and 7-1 positions. The reactivity of the NBSR is controlled with four cadmium shim arms that are rotated through the core in a semaphore fashion.

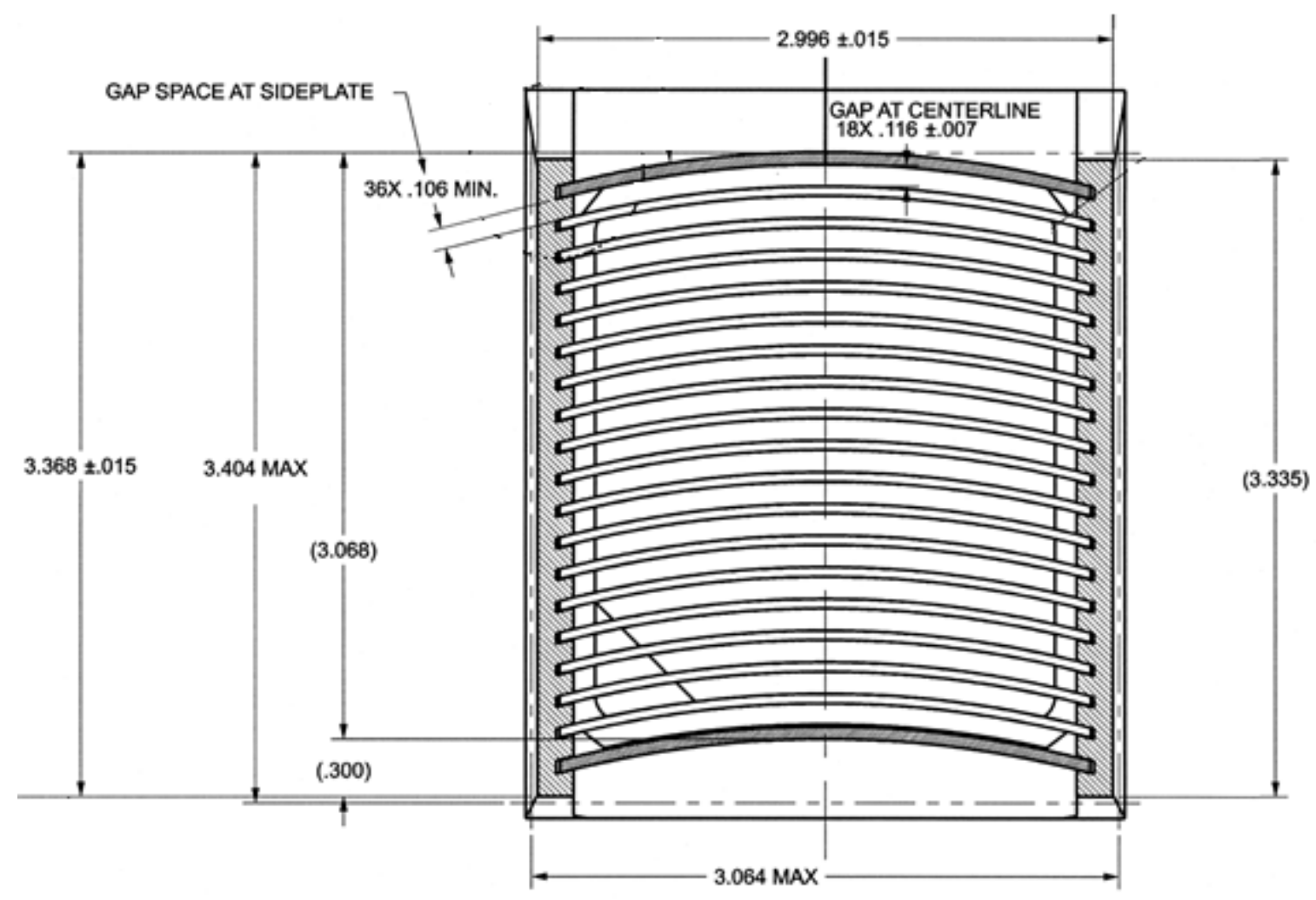

Figure 3 Cross Sectional View of Fuel Element (Dimensions in Inches) 


\section{COLD SOURCE}

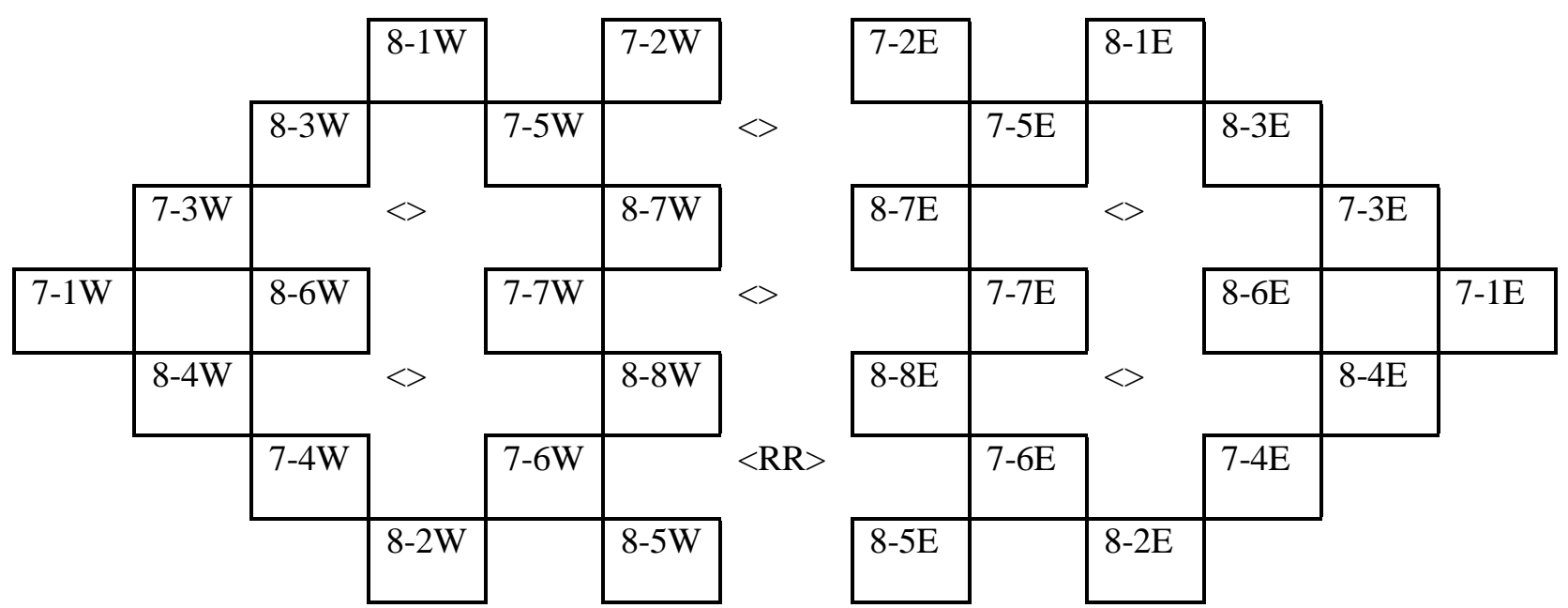

Figure 4 NBSR Fuel Management Scheme

For the conversion of the reactor to LEU fuel, an improved full-core model of the NBSR has been developed (the "present" model) for the neutronic and burn-up analysis [2]. The model utilizes MCNPX [9] to accomplish a detailed burn-up analysis where each half-element has a unique fuel inventory (material composition) that is moved throughout the core for either seven or eight 38.5-day fuel cycles. The NBSR model has been subjected to a variety of validation studies and is an evolution of the model utilized in the NBSR Safety Analysis Report [1]. It has also been utilized to design two cold neutron sources, and to compute the prompt neutron lifetime [2]. A planar view of the NBSR model is shown in Figure 5. Some of the specific improvements made to the burn-up analysis in the present full-core model include [2]:

- reduction in unaccounted mass from $\sim 1.2 \%$ per cycle per fuel element to $\sim 0.13 \%$ per cycle per fuel element

- increase of the number of isotopes considered from a maximum of 63 to a maximum of 210

- increase of the number of fuel inventories from 30 to 60 eliminating forced symmetry radially, in the half fuel elements' material compositions

- inclusion of the 10.5-day decay time at the end of each cycle

- analysis of additional burn-up state points

- utilization of the ENDF-B/VII.0 cross section libraries

- realistic positioning of the shim arms (control elements) within each burn-up state point 


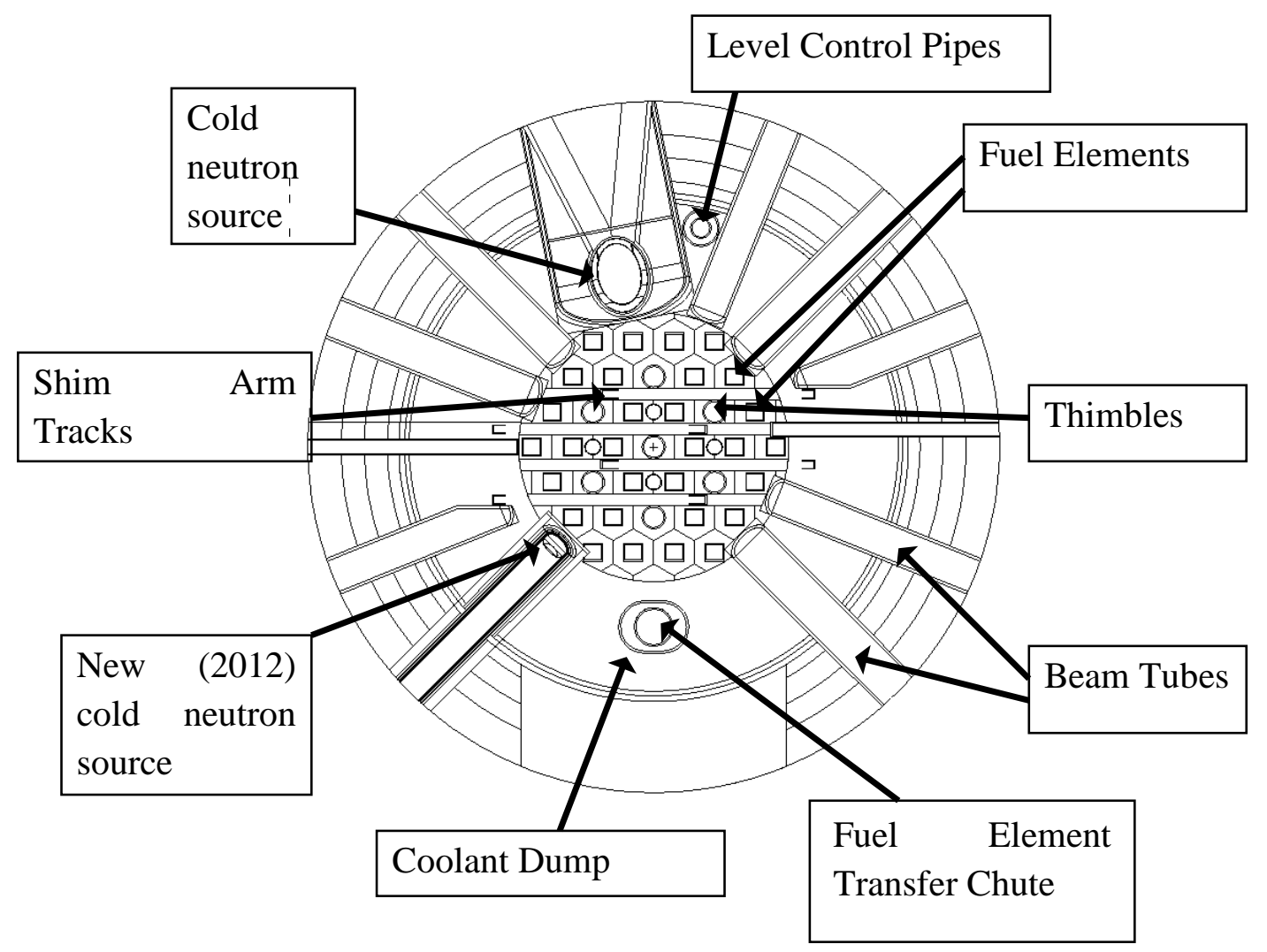

Figure 5 Planar View of the NBSR MCNPX Model

\section{Limiting LEU Power Distribution}

The purpose of this section is to inform the design and planning of future irradiation experiments by documenting the calculated fission rate density and heat flux distribution in the LEU NBSR. For evaluation of the fission distribution in the NBSR core, a large number of nodes for the fuel plates were used in the MCNPX analysis [3]. Figure 6 shows an elevation view with the axial discretization of the fuel element geometry in the MCNPX model. The plates are modeled without curvature for simplification. The choice of mesh size for the MCNPX calculations is based on the observation that heat conduction in a fuel plate will result in a lateral heat flux profile (i.e. across the width of a fuel plate) that is flatter than the profile of the energy deposition due to fission [10]. The heat conduction problem was analyzed both analytically [10] and numerically [11]. The results indicate the average surface energy flux (sum of energy deposition divided by the surface area of a mesh cell) for a $4 \mathrm{~cm}^{2}$ mesh conservatively captures the maximum wall heat flux determined by solving the heat conduction problem for a fuel plate. Using this information as guidance for the evaluation of power distribution in the core, the MCNPX calculations employed mesh cells (nodes) with a width of about $2 \mathrm{~cm}$ and a height of about $2 \mathrm{~cm}$. There are three cells in the lateral direction and 14 cells in the axial direction per fuel plate. The total number of cells used for the MCNPX analysis is calculated as below. 


$$
\begin{gathered}
N_{T O T-C}=\left(\begin{array}{c}
\text { Number of cells in lateral direction }) \cdot(\text { Number of cells in axial direction }) \\
\cdot(\text { Number of plates per fuel element }) \cdot(\text { Number of fuel elements })
\end{array}\right. \\
N_{\text {TOT-C }}=3 \times 14 \times(2 \times 17) \times 30=42,840
\end{gathered}
$$

The number of fissions in each cell has been calculated for HEU and LEU fuels at startup (SU), the limiting core condition in terms of the local heat flux and fission rate density, and end-ofcycle (EOC), the limiting core condition in terms of the fission density. It is assumed that all fission energy is deposited directly in the NBSR fuel and within the cell that contains the fission. This assumption is conservative because in reality a small fraction of the fission energy will be deposited directly in the cladding, coolant, moderator, and reactor structural material. Detailed descriptions of the evaluation of power distribution and kinetic parameters by using the MCNPX computer code are presented in [2].

The average fission rate density in the NBSR is calculated based on the core power, the number of nodes in the core, and the volume of each node. The dimensions of each node are $1.9957 \mathrm{~cm} \times 2.04 \mathrm{~cm} \times 0.0215 \mathrm{~cm}$. In the proposed LEU U10Mo fuel the average fission rate density is,

$$
\begin{aligned}
& \text { Average fission rate density }\left[\frac{\text { fission }}{\mathrm{cm}^{3}-\mathrm{s}}\right]=(\text { core thermal power }) \times \frac{1}{(\text { fuel volume })} \\
& \qquad=\frac{20 \times 10^{6} \mathrm{~W}}{200 \times 10^{6} \mathrm{eV} \times 1.602 \times 10^{-19} \frac{\mathrm{J}}{\mathrm{eV}}} \\
& \quad \times \frac{1}{42840 \times 1.9957 \mathrm{~cm} \times 2.04 \mathrm{~cm} \times 0.0215 \mathrm{~cm}}=1.657 \times 10^{14} \frac{\text { fission }}{\mathrm{cm}^{3}-\mathrm{s}}
\end{aligned}
$$




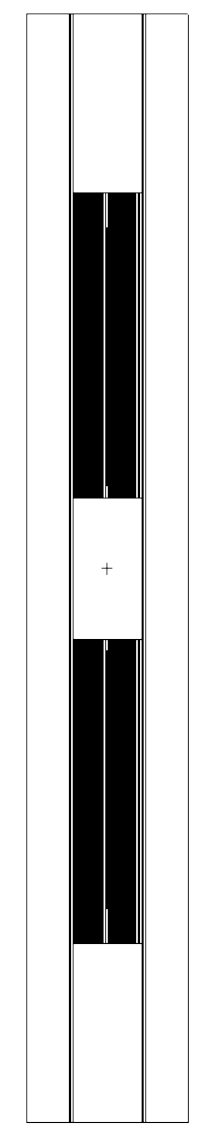

Elevation view

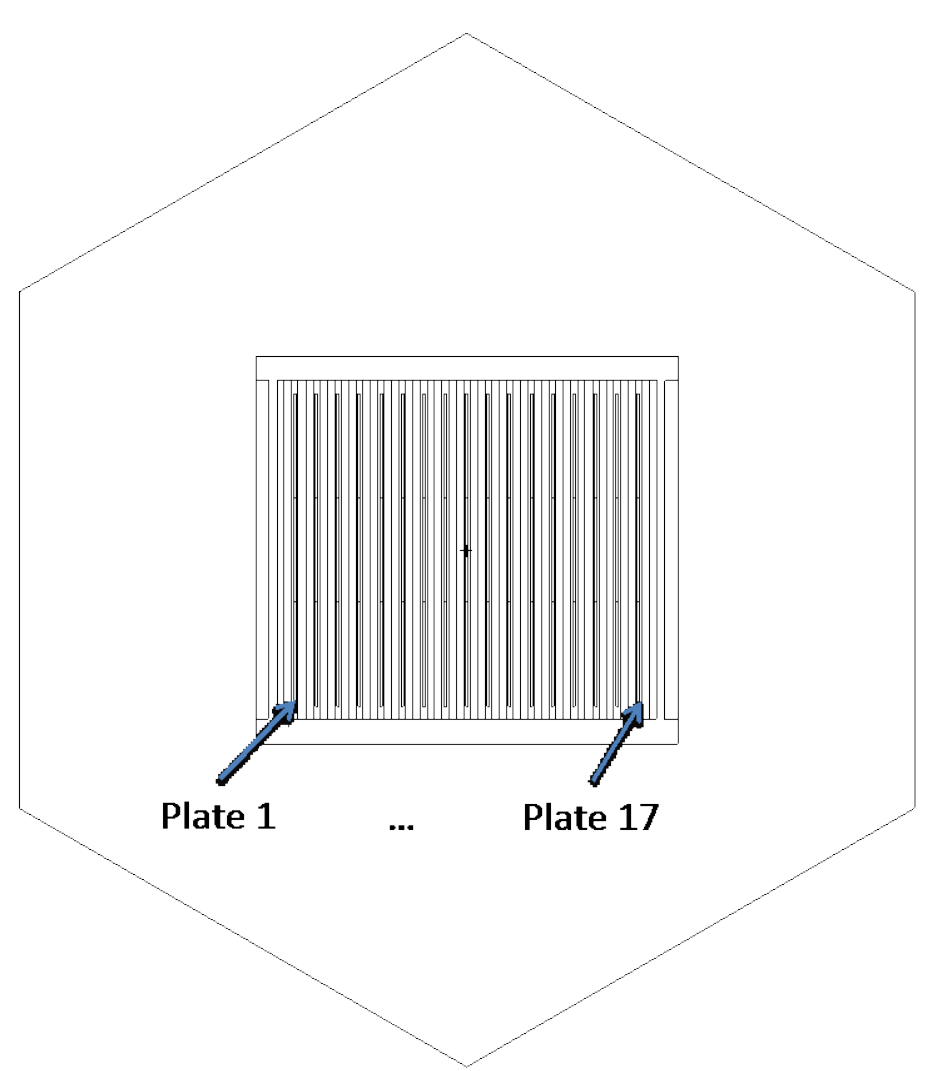

Elevation view showing axial and lateral power distribution nodalization in each plate

Figure 6 NBSR Fuel Element Geometry in the MCNPX Model 
The maximum fission rate density is calculated utilizing the average fission rate density and the node peaking factor. The node peaking factor is the ratio of the peak number of fissions-pernode to the average number of fissions per node, as calculated utilizing the MCNPX model. For the proposed LEU fuel the maximum fission rate density is,

$$
\begin{aligned}
& \text { Maximum fission rate density }\left[\frac{\text { fission }}{\mathrm{cm}^{3}-\mathrm{s}}\right] \\
& =(\text { average fission rate density }) \times(\text { node peaking factor }) \\
& =1.657 \times 10^{14} \frac{\text { fission }}{\mathrm{cm}^{3}-\mathrm{s}} \times 2.431=4.029 \times 10^{14} \frac{\text { fission }}{\mathrm{cm}^{3}-\mathrm{s}}
\end{aligned}
$$

The limiting core heat flux distribution occurs at SU with fresh shim arms. The core power is more evenly distributed when the shim arms are withdrawn from the core or in a depleted state, because the flux compression in the upper-half of the NBSR core (due to the shim arms) is reduced. This reduces the magnitude of the hot spots and increases the minimum critical heat flux ratio (CHFR). The plate-wise heat flux distributions are plotted in Figure 7 - Figure 10 for the elements with hot spots (maximum number of fissions-per-node) and in Figure 11 - Figure 14 for the elements with hot stripes (maximum number of fissions per vertical stripe). Plots are included for both Plate 1 and Plate 17; however, due to the orientation of the fuel elements within the core, the hot spots and hot stripes always occur in plate 17. In addition to the limiting cases, the heat flux distributions are also provided for a fresh element, 8-1E, in Figure 15 and Figure 16.

The axial dimension of the fuel element is relative to the axial center of the mid-plane gap ( $\mathrm{z}=$ $0.0 \mathrm{~cm})$ and the lateral dimension is relative to the lateral center of the fuel plate $(\mathrm{y}=0.0 \mathrm{~cm})$. The node maximum heat flux of $1394 \mathrm{~kW} / \mathrm{m}^{2}$, corresponding to the maximum fission rate density and a peaking factor of 2.431, occurs on plate 17 of element 8-3E. Element 8-3E is a relatively fresh element, having experienced only two 38.5 day cycles of irradiation. Heat flux distributions are shown for both the inner and outer flow plenum locations. Additionally, the heat flux distributions are shown with fresh shim arms and with shim arms that have been irradiated for twenty-five cycles. The heat flux distribution results for irradiated shim arms are derived from the results of a recent study [9]. To convert a local heat flux to a fission rate density,

$$
\text { Fission rate density }\left[\frac{\text { fission }}{\mathrm{cm}^{3}-\mathrm{s}}\right]=q^{\prime \prime}\left(\frac{\mathrm{kW}}{\mathrm{m}^{2}}\right) \times 2.890 \times 10^{11} \frac{\text { fission }}{\mathrm{cm}^{3}-\mathrm{s}}\left(\frac{\mathrm{m}^{2}}{\mathrm{~kW}}\right)
$$




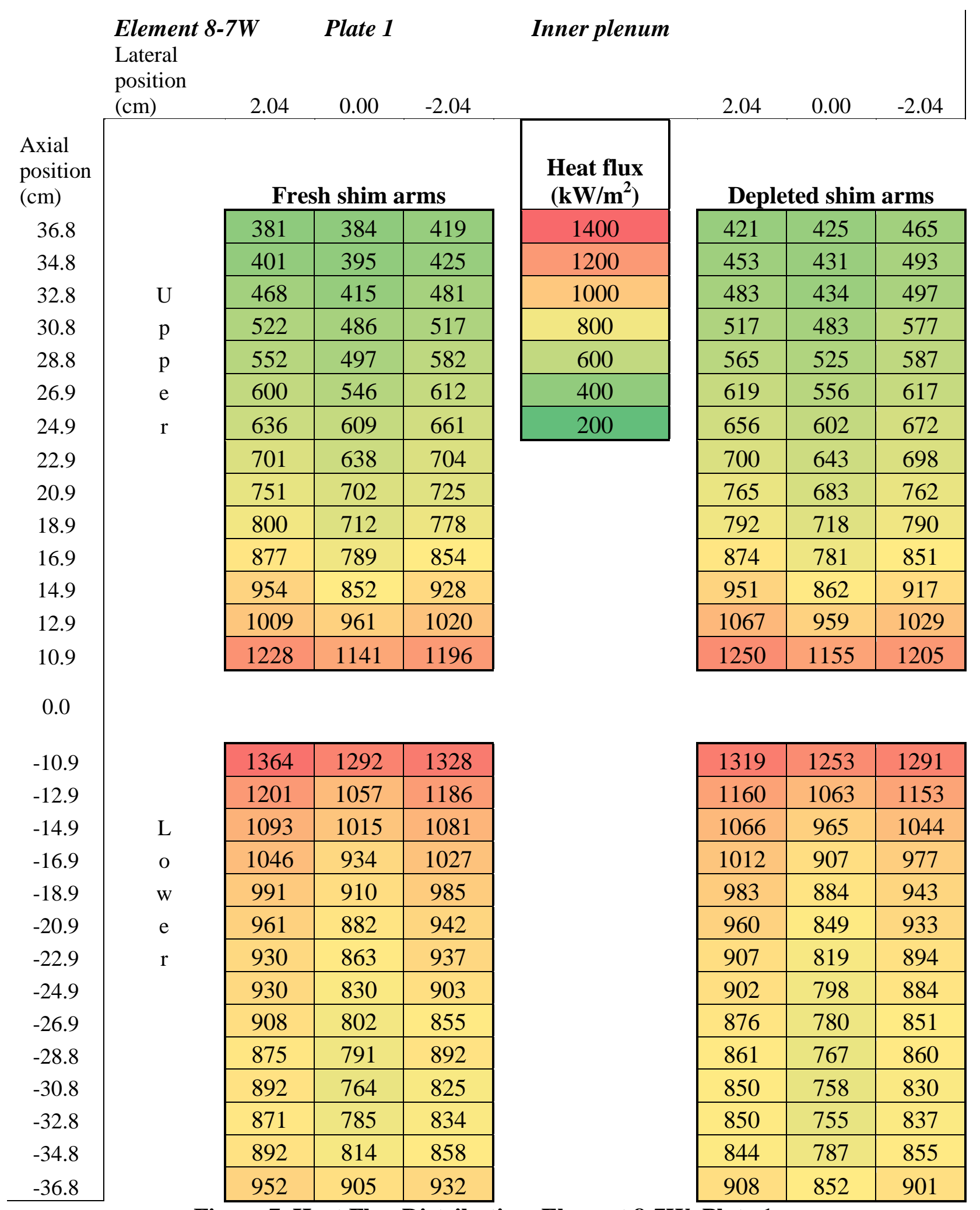

Figure 7 Heat Flux Distribution, Element 8-7W, Plate 1 


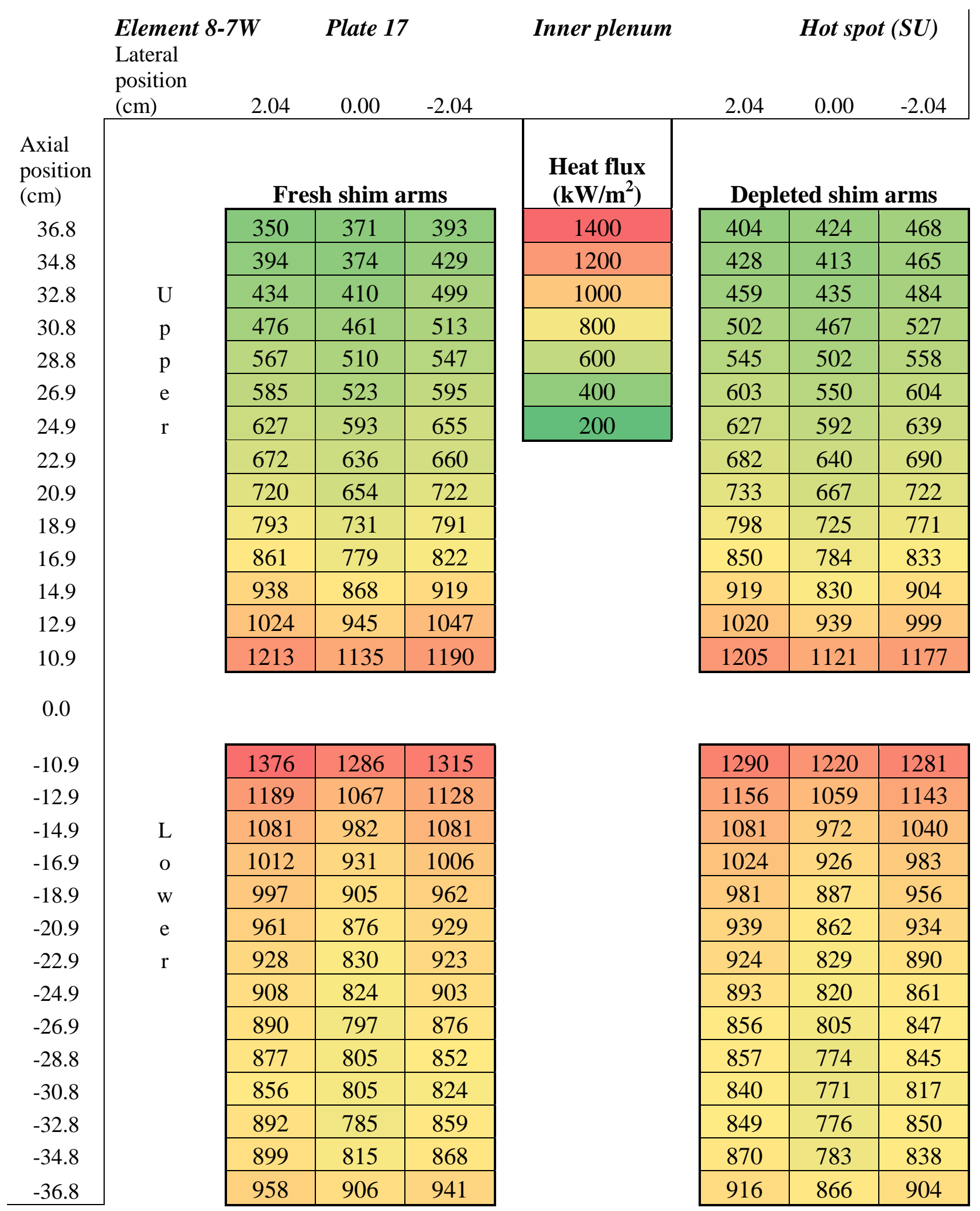

Figure 8 Heat Flux Distribution, Element 8-7W, Plate 17 


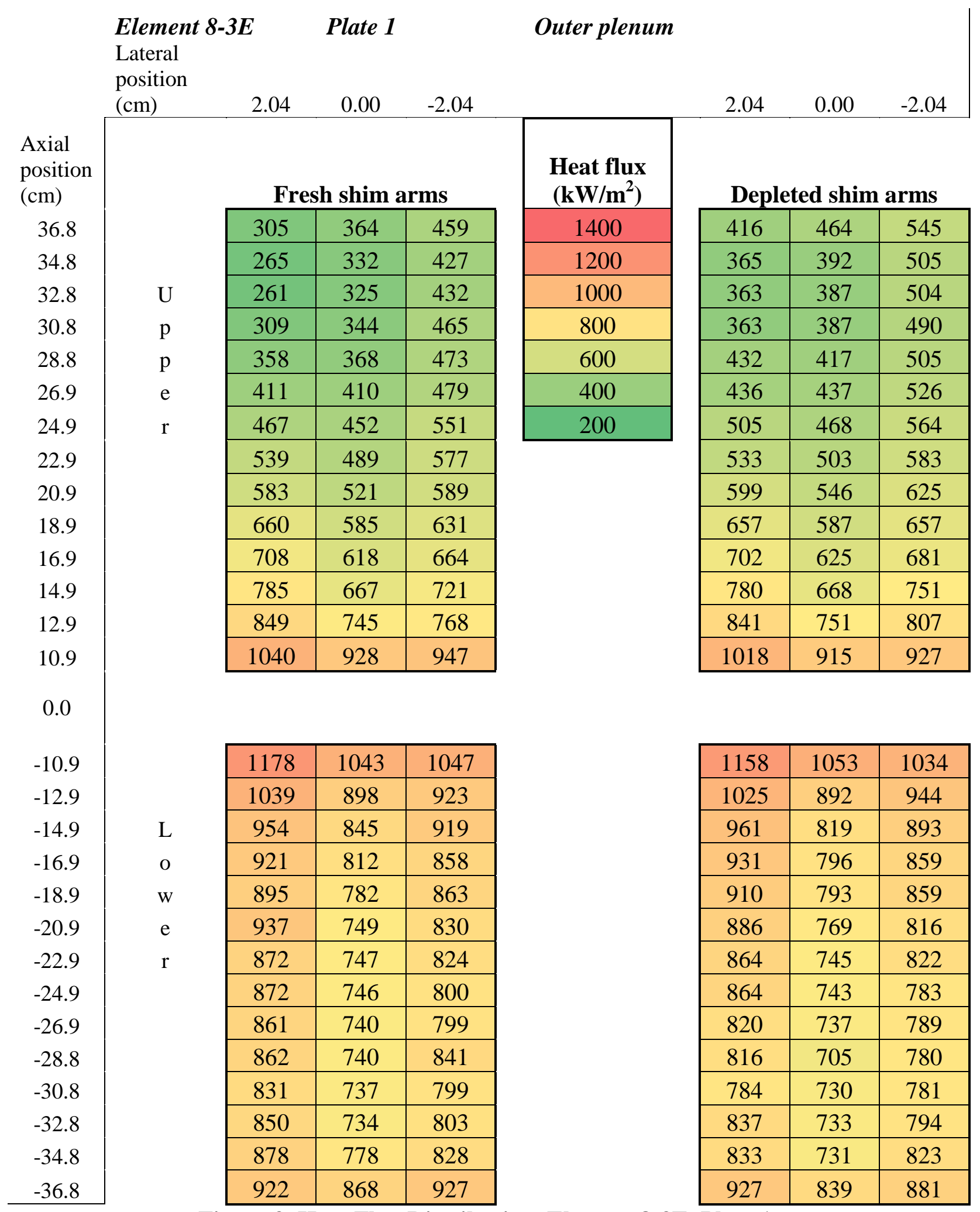

Figure 9 Heat Flux Distribution, Element 8-3E, Plate 1 


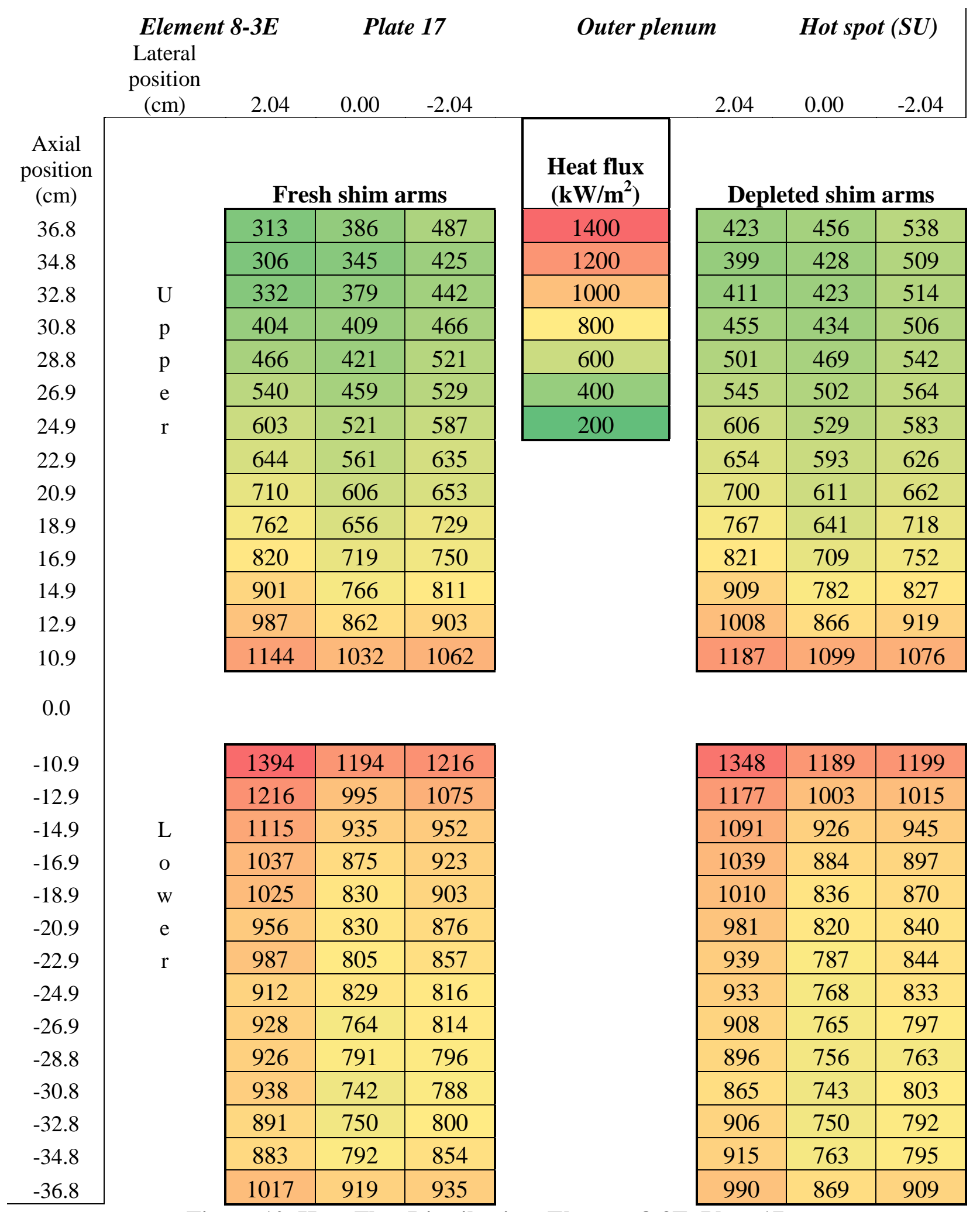

Figure 10 Heat Flux Distribution, Element 8-3E, Plate 17 


\section{Element 8-7E}

Lateral

position

Plate 1

Inner plenum

\begin{tabular}{|c|c|c|c|c|c|c|c|c|}
\hline & & 2.04 & 0.00 & -2.04 & & 2.04 & 0.00 & -2.04 \\
\hline $\begin{array}{l}\text { Axial } \\
\text { position } \\
\text { (cm) }\end{array}$ & \multirow[b]{4}{*}{$\mathrm{U}$} & \multicolumn{3}{|c|}{ Fresh shim arms } & $\begin{array}{c}\text { Heat flux } \\
\left(\mathrm{kW} / \mathrm{m}^{2}\right)\end{array}$ & \multicolumn{3}{|c|}{ Depleted shim arms } \\
\hline 36.8 & & 387 & 354 & 330 & 1400 & 420 & 387 & 398 \\
\hline 34.8 & & 403 & 357 & 347 & 1200 & 432 & 378 & 418 \\
\hline 32.8 & & 428 & 394 & 406 & 1000 & 472 & 419 & 444 \\
\hline 30.8 & \multirow{3}{*}{$\begin{array}{l}\mathrm{p} \\
\mathrm{p} \\
\mathrm{e}\end{array}$} & 485 & 453 & 486 & 800 & 499 & 443 & 492 \\
\hline 28.8 & & 523 & 494 & 535 & 600 & 556 & 487 & 533 \\
\hline 26.9 & & 589 & 534 & 572 & 400 & 582 & 540 & 576 \\
\hline 24.9 & \multirow[t]{8}{*}{$\mathrm{r}$} & 641 & 568 & 606 & 200 & 648 & 591 & 619 \\
\hline 22.9 & & 661 & 605 & 667 & & 670 & 628 & 688 \\
\hline 20.9 & & 751 & 641 & 731 & & 725 & 670 & 715 \\
\hline 18.9 & & 775 & 713 & 786 & & 775 & 709 & 784 \\
\hline 16.9 & & 862 & 789 & 824 & & 836 & 771 & 833 \\
\hline 14.9 & & 909 & 825 & 914 & & 914 & 834 & 885 \\
\hline 12.9 & & 1048 & 905 & 1028 & & 1011 & 934 & 980 \\
\hline 10.9 & & 1183 & 1104 & 1176 & & 1199 & 1111 & 1182 \\
\hline \multicolumn{9}{|l|}{0.0} \\
\hline-10.9 & \multirow[b]{3}{*}{$\mathrm{L}$} & 1355 & 1277 & 1321 & & 1332 & 1242 & 1295 \\
\hline-12.9 & & 1187 & 1102 & 1164 & & 1149 & 1069 & 1149 \\
\hline-14.9 & & 1074 & 977 & 1075 & & 1051 & 966 & 1055 \\
\hline-16.9 & 0 & 1033 & 940 & 1036 & & 1019 & 930 & 1012 \\
\hline-18.9 & \multirow{2}{*}{$\begin{array}{l}\mathrm{w} \\
\mathrm{e}\end{array}$} & 985 & 899 & 1019 & & 985 & 874 & 935 \\
\hline-20.9 & & 960 & 876 & 957 & & 928 & 839 & 925 \\
\hline-22.9 & \multirow[t]{2}{*}{$r$} & 945 & 812 & 910 & & 931 & 820 & 885 \\
\hline-24.9 & & 920 & 828 & 896 & & 894 & 830 & 880 \\
\hline-26.9 & & 896 & 822 & 887 & & 875 & 795 & 862 \\
\hline-28.8 & & 851 & 795 & 863 & & 839 & 759 & 824 \\
\hline-30.8 & & 875 & 807 & 836 & & 832 & 760 & 809 \\
\hline-32.8 & & 872 & 781 & 834 & & 856 & 768 & 813 \\
\hline-34.8 & & 878 & 799 & 847 & & 841 & 789 & 832 \\
\hline-36.8 & & 944 & 875 & 948 & & 927 & 862 & 900 \\
\hline
\end{tabular}

Figure 11 Heat Flux Distribution, Element 8-7E, Plate 1 


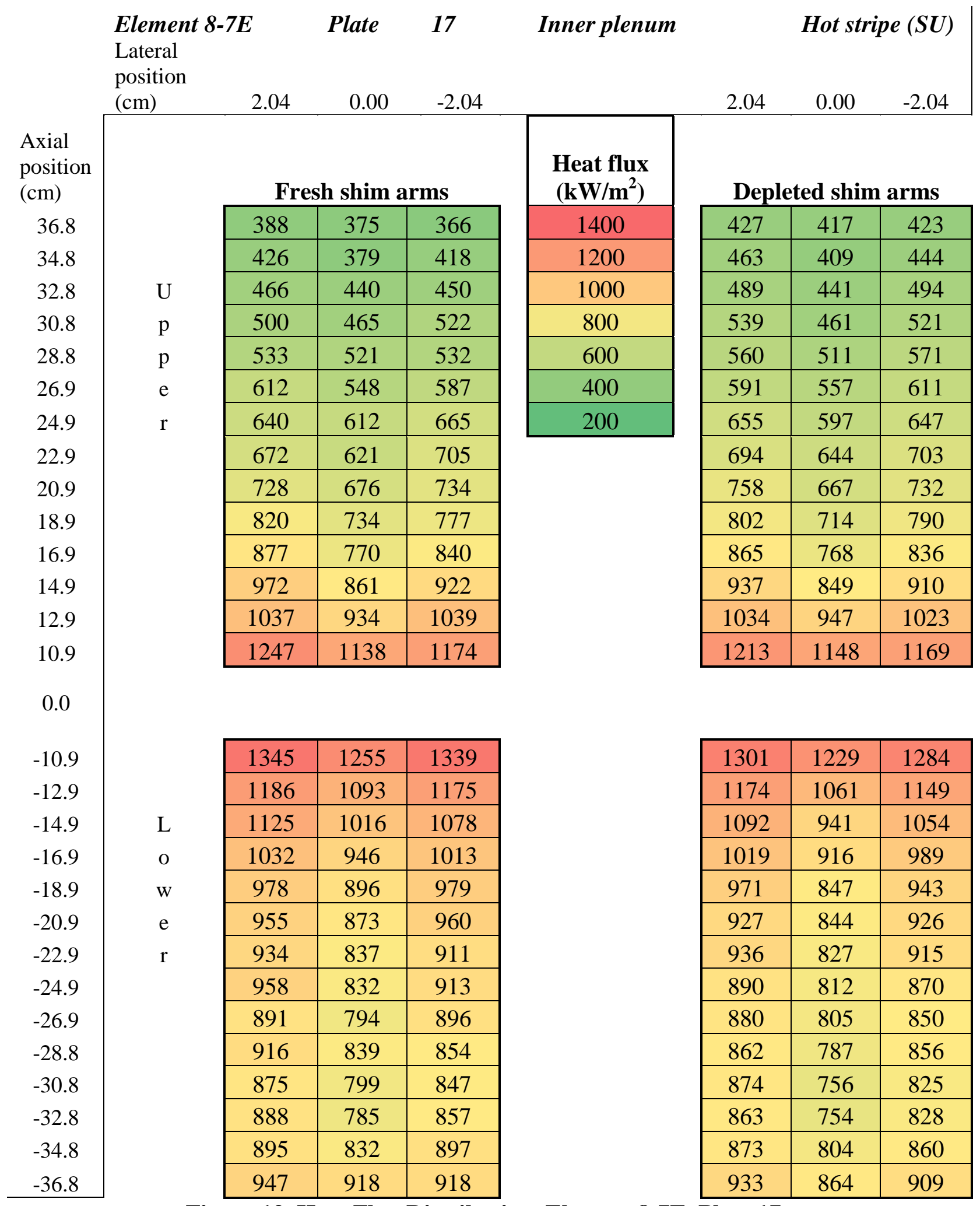

Figure 12 Heat Flux Distribution, Element 8-7E, Plate 17 


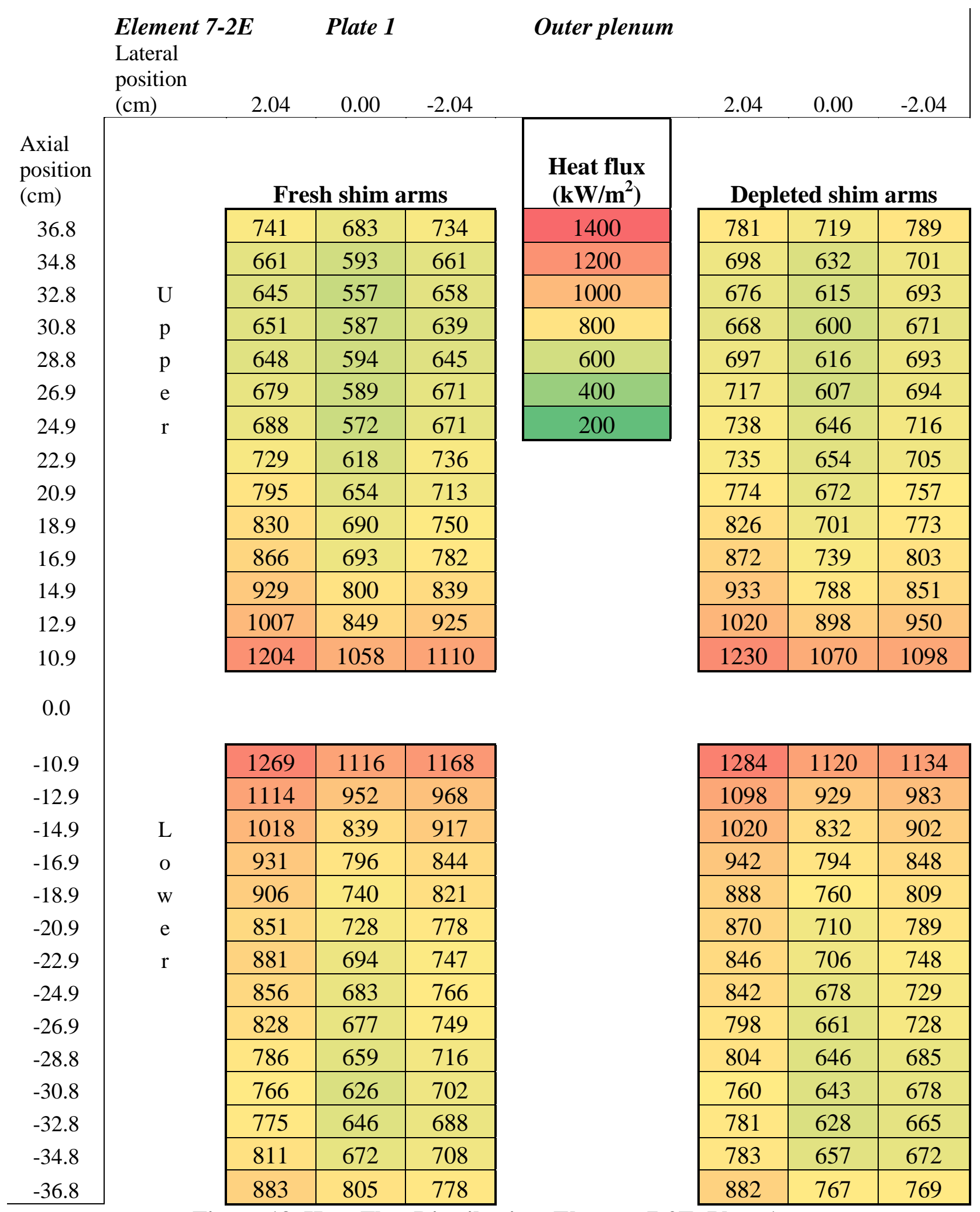

Figure 13 Heat Flux Distribution, Element 7-2E, Plate 1 


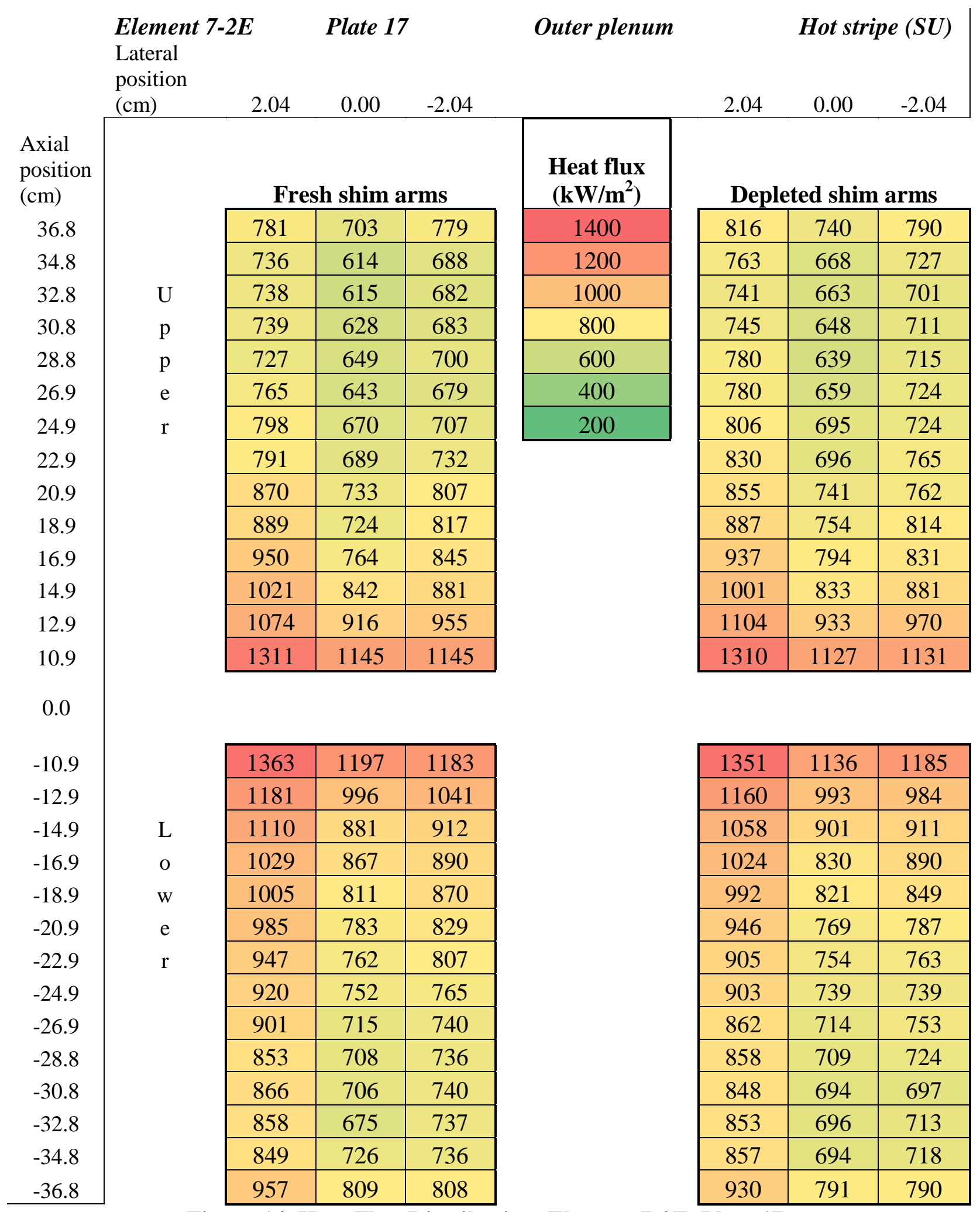

Figure 14 Heat Flux Distribution, Element 7-2E, Plate 17 


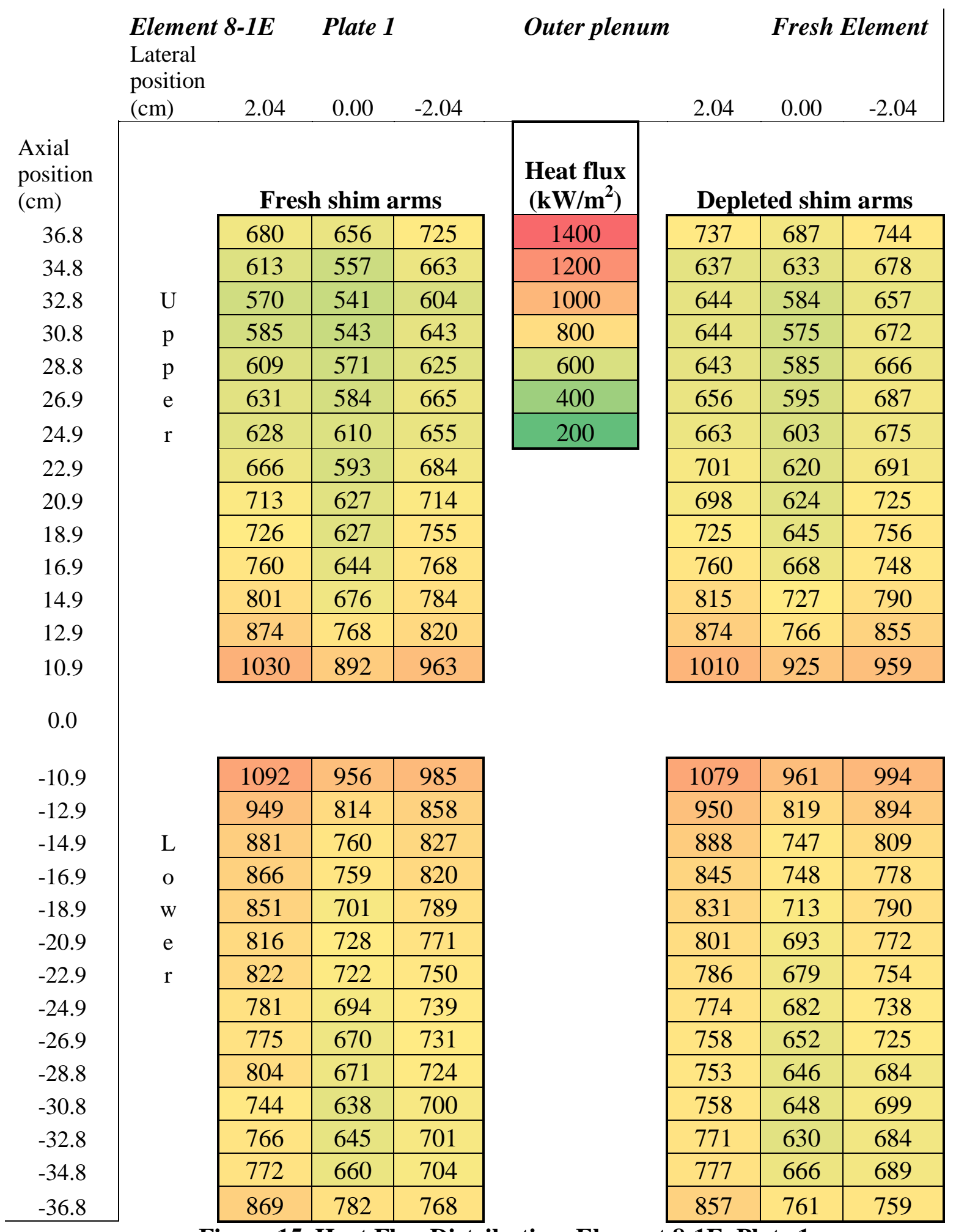

Figure 15 Heat Flux Distribution, Element 8-1E, Plate 1 


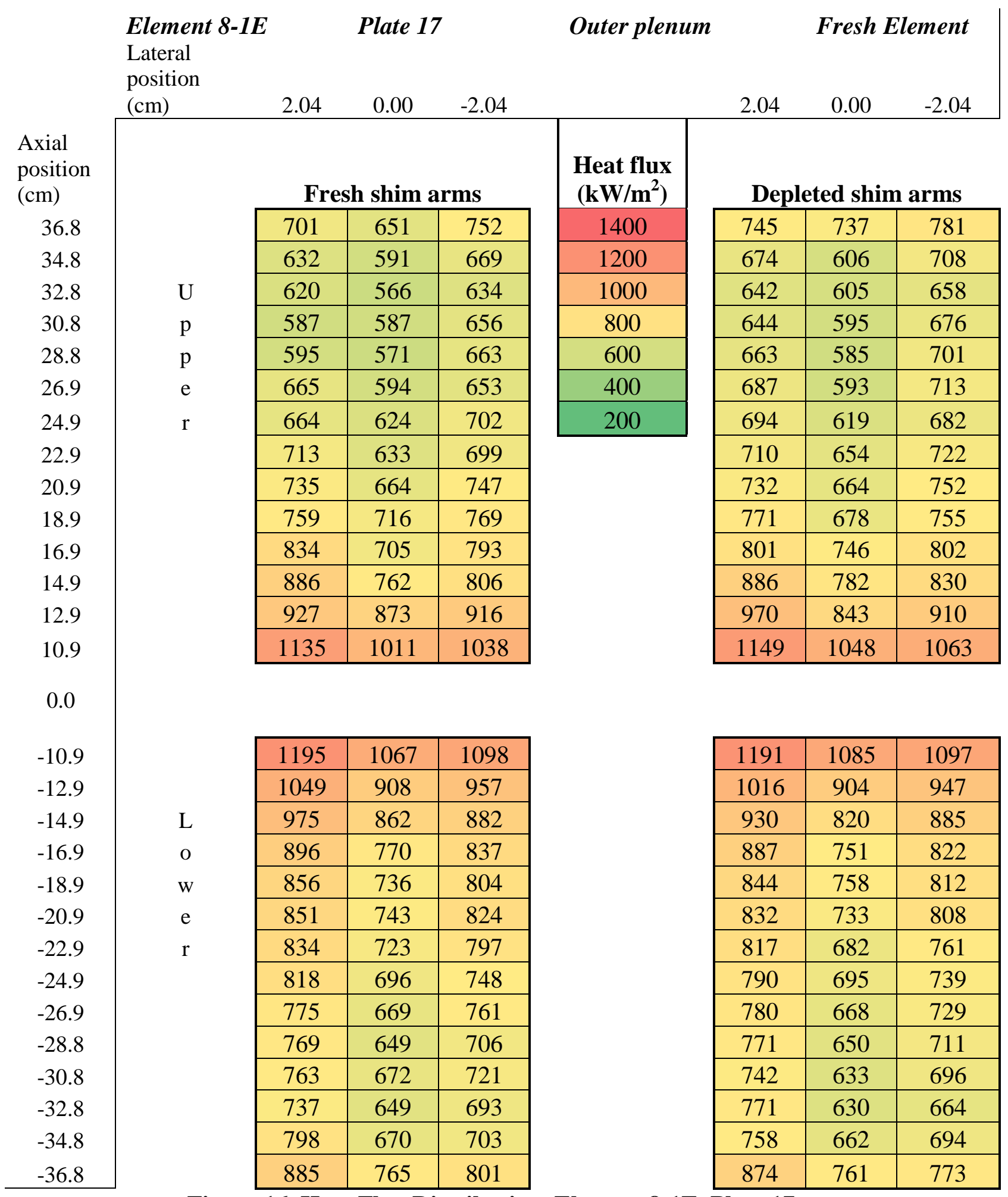

Figure 16 Heat Flux Distribution, Element 8-1E, Plate 17 


\section{Limiting LEU Local Burn-Up and Fission Density}

The purpose of this section is to inform the design and planning of future irradiation experiments by documenting the calculated cumulative fission density in the LEU NBSR. The calculation of the average cumulative fission density depends on the average fission rate density and the average core residence time ( 7.5 cycles of 38.5 days),

$$
\begin{aligned}
& \text { Average fission density }\left[\frac{\text { fission }}{\mathrm{cm}^{3}}\right] \\
& \quad=(\text { average fission rate density }) \times(\text { core residence time }) \\
& =1.657 \times 10^{14} \frac{\text { fission }}{\mathrm{cm}^{3}-\mathrm{s}} \times 7.5 \times 38.5 \text { day } \times \frac{86400 \mathrm{~s}}{\text { day }}=4.134 \times 10^{21} \frac{\text { fission }}{\mathrm{cm}^{3}}
\end{aligned}
$$

The maximum fission density depends on the local burn-up. In the equilibrium LEU core model the fuel inventories are homogenized within each half-element. However, recent studies have investigated the distribution of burn-up within the NBSR half-element [5]. These studies have shown two effects: (1) the impact of the mid-plane gap on axial burn-up and (2) the impact of the plate-to-plate self-shielding on the plate-wise burn-up. The impact of these two effects has not been considered synergistically. The study was accomplished via a single element model without shim arms. Thus, the impact of the shim arms, which will increase the local fission density in the lower half-element and decrease the local fission density in the upper half-element, is not reflected in these results. However, these results provide a useful estimate of the "average" of the upper and lower half-element axial fission density distribution and illustrate the impact of the mid-plane gap on the local fission density due to thermal flux peaking.

Two models are utilized to study two local burn-up effects separately. One model utilizes an axial burn-up cell nodalization, and the other model utilizes a plate-wise cell nodalization. The study of axial burn-up distribution used an axial nodalization that is the same as the nodalization used to extract the power distribution, but the plate-wise and lateral nodalization is not the same. The main difference between the nodalization in the axial burn-up model and the nodalization in the power distribution full-core model, is that the axial nodes span all seventeen plates within the axial burn-up model. Additionally, each axial node also spans all three lateral nodes. Because the shim arms are not included in the models utilized for local burn-up quantification, the upper and lower half-elements are symmetric, for a total of fourteen unique axial depletion nodes. The cumulative EOC axial burn-up is shown as fission density in Figure 17 and the LEU axial fission density distribution at EOC of Cycle 8 is shown in Figure 18. In Figure 17 Node 1 represents the two depletion nodes closest to the mid-plane gap and Node 14 represents the two depletion nodes on the top and bottom of the fuel element. The colors correspond to the different nodes. Due to the large number of nodes some colors are repeated. The axial height of the fuel element is relative to the axial center of the mid-plane gap $(\mathrm{z}=0.0 \mathrm{~cm})$. The mid-plane gap is evident in Figure 18. 
In the plate-wise burn-up case nine plates are considered, with each plate treated as a single burn-up node, accounting for symmetry within the fuel element (eight "symmetric" plates and one central plate). For example, Plate 1 is considered to be symmetric with Plate 17, Plate 2 is symmetric with Plate 16, etcetera. The cumulative plate-wise burn-up is shown as fission density in Figure 19.

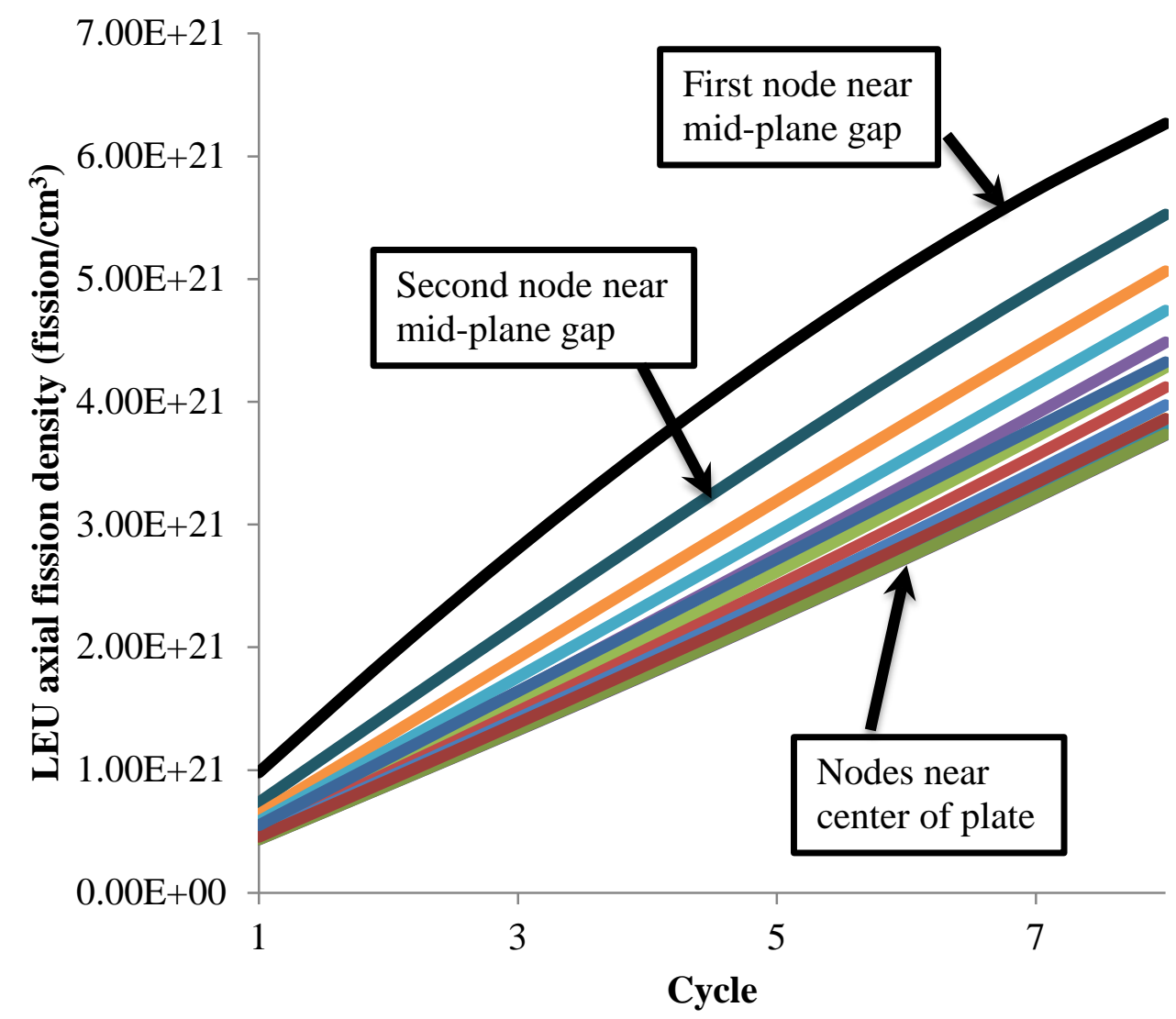

$\longrightarrow$ Node 1

Node 2

Node 3

Node 4

Node 5

Node 6

Node 7

Node 8

Node 9

Node 10

Node 11

Node 12

Node 13

Node 14

Figure 17 LEU Cumulative Fission Density at EOC 


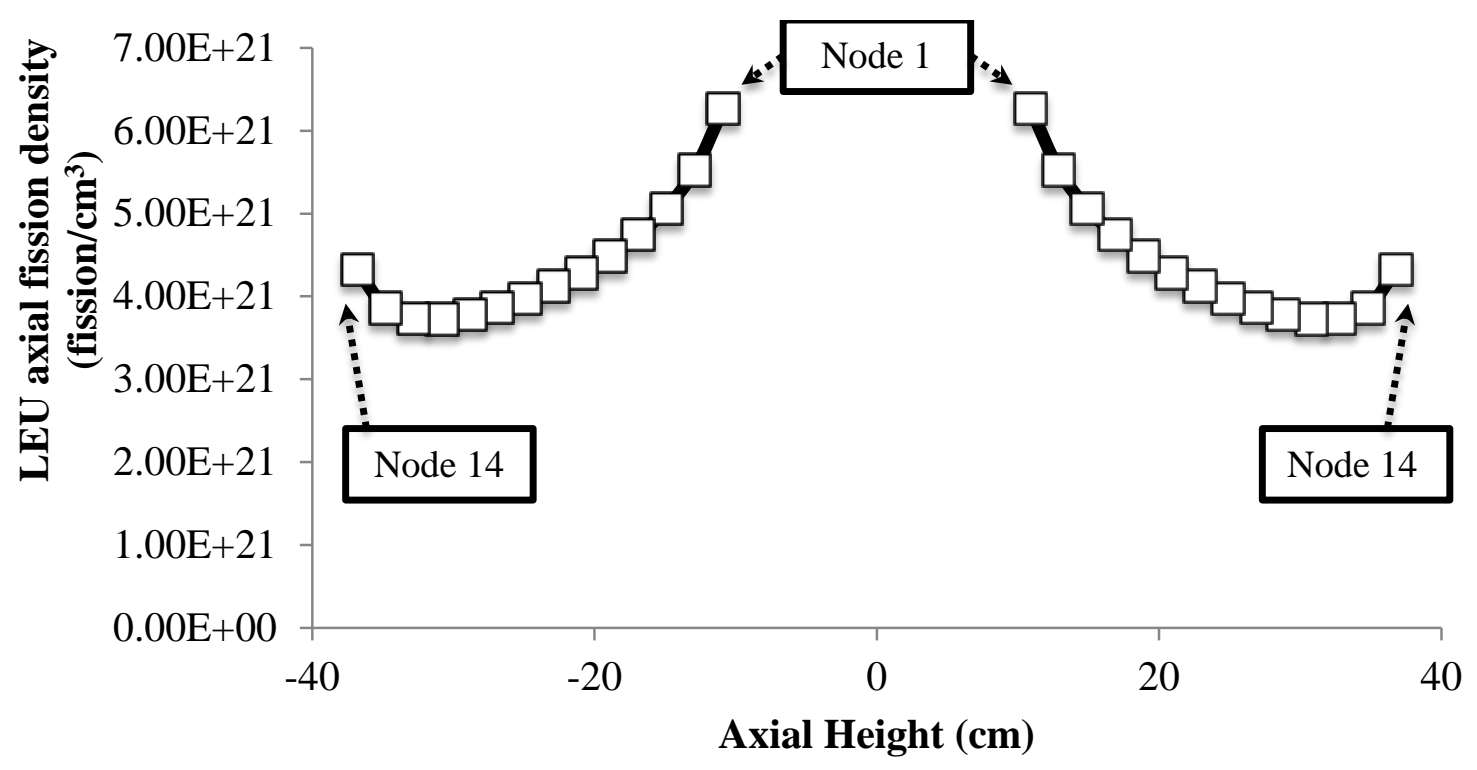

Figure 18 LEU Average Axial Fission Density Distribution at Cycle 8 EOC

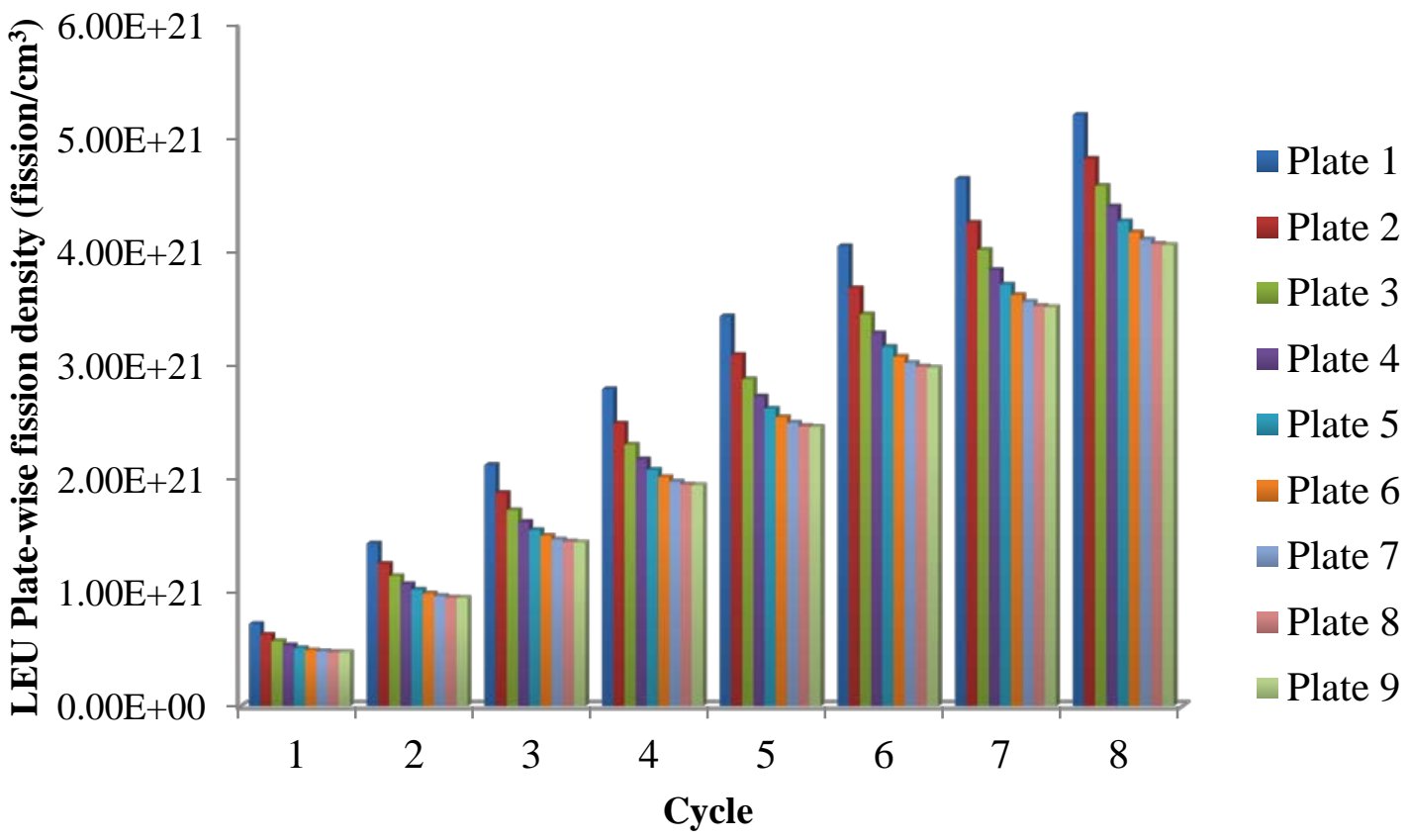

Figure 19 LEU Plate-Wise Fission Density at EOC

To approximate the maximum fission density, the maximum node burn-up at eight cycles was divided by the average node burn-up at 7.5 cycles to yield axial and plate-wise burn-up factors. The maximum fission density, which would occur at an outer fuel plate that is adjacent to the mid-plane gap, is calculated as, 
Maximum fission density $\left[\frac{\text { fission }}{\mathrm{cm}^{3}}\right]$

$$
\begin{aligned}
& \approx \text { (average fission density) } \times \frac{(\text { maximum axial burnup })}{(\text { average axial burnup) }} \times \frac{(\text { maximum plate }- \text { wise burnup) }}{\text { (average plate }- \text { wise burnup) }} \\
& =4.134 \times 10^{21} \frac{\text { fission }}{\mathrm{cm}^{3}} \times \frac{150.5 \mathrm{GWd} / \mathrm{t}}{99.29 \mathrm{GWd} / \mathrm{t}} \times \frac{124.4 \mathrm{GWd} / \mathrm{t}}{98.81 \mathrm{GWd} / \mathrm{t}}=7.888 \times 10^{21} \frac{\text { fission }}{\mathrm{cm}^{3}}
\end{aligned}
$$

This approximate calculation is physically realizable only if there is sufficient available fissile material to accommodate this local fission density. The initial atom density of ${ }^{235} \mathrm{U}$ is,

$$
\begin{aligned}
& \text { Initial atom density of } U-235\left[\frac{\text { atom }}{\mathrm{cm}^{3}}\right]=\frac{(\text { mass of } U-235)}{(\text { fuel volume })} \times \frac{\left(6.022 \times 10^{23} / \mathrm{mol}\right)}{(235.04 \mathrm{~g} / \mathrm{mol})} \\
& =\frac{(383 \mathrm{~g})}{\left(62.6408 \mathrm{~cm}^{3} \times 2\right)} \times \frac{\left(6.022 \times 10^{23} \text { atom }\right)}{(235.04 \mathrm{~g})}=7.833 \times 10^{21} \frac{\text { atom }}{\mathrm{cm}^{3}}
\end{aligned}
$$

The average atom density of ${ }^{239} \mathrm{Pu}$ at EOL (cycle 8) is,

$$
\begin{gathered}
\text { Cycle } 8 \text { atom density of } \mathrm{Pu}-239\left[\frac{\text { atom }}{\mathrm{cm}^{3}}\right]=\frac{(\text { mass of } \mathrm{Pu}-239)}{(\text { fuel volume })} \times \frac{\left(6.022 \times 10^{23} / \mathrm{mol}\right)}{(239.05 \mathrm{~g} / \mathrm{mol})} \\
=\frac{(7.20 \mathrm{~g})}{\left(62.6408 \mathrm{~cm}^{3} \times 2\right)} \times \frac{\left(6.022 \times 10^{23} \text { atom }\right)}{(239.05 \mathrm{~g})}=0.145 \times 10^{21} \frac{\text { atom }}{\mathrm{cm}^{3}}
\end{gathered}
$$

Thus, the calculated fission density is physically realizable in the LEU NBSR. To provide context, Table 2 shows the fraction of fissions that occur due to each fissile or fissionable nuclide in the LEU NBSR [2]. At SU and EOC, the two fissile nuclides ${ }^{235} \mathrm{U}$ and ${ }^{239} \mathrm{Pu}$ account for over $99 \%$ of fissions in the LEU NBSR. The local burn-up of ${ }^{235} \mathrm{U}$ will certainly approach $100 \%$ within the NBSR.

\section{Table 2 Fraction of Fissions in the LEU NBSR}

\begin{tabular}{|c|c|c|}
\hline & LEU SU & LEU EOC \\
\hline${ }^{235} \mathrm{U}$ & 96.35 & 95.71 \\
\hline${ }^{236} \mathrm{U}$ & 0.02 & 0.02 \\
\hline${ }^{238} \mathrm{U}$ & 0.49 & 0.49 \\
\hline${ }^{239} \mathrm{Pu}$ & 2.99 & 3.54 \\
\hline${ }^{241} \mathrm{Pu}$ & 0.16 & 0.24 \\
\hline
\end{tabular}

By utilizing the plate-wise burn-up factors the axial fission density distribution is approximated for several plates in Figure 20. Figure 20 highlights the fact that the majority of the fuel plates result in similar cumulative burn-up, with the exception of the outer plates. The fission densities values plotted in Figure 20 are shown in Table 3. 


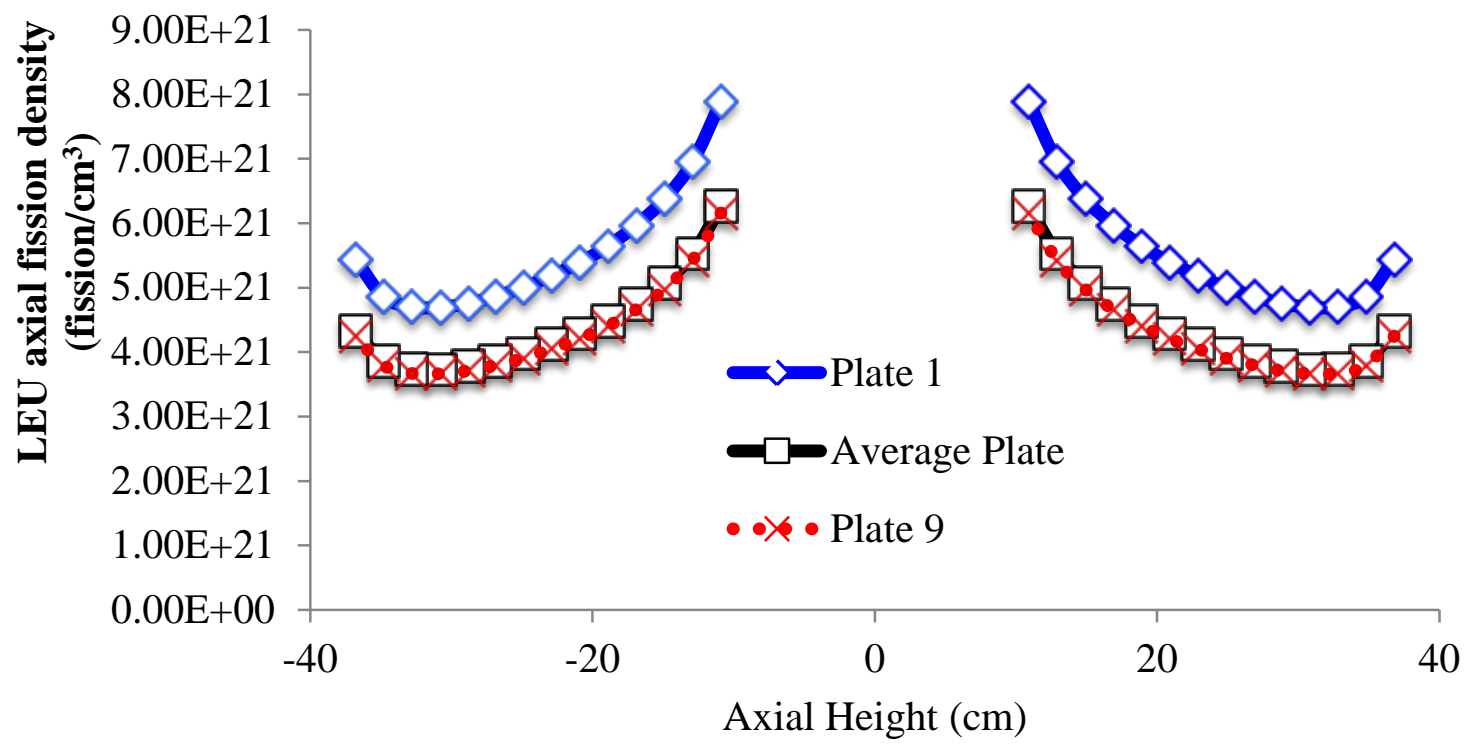

Figure 20 LEU Axial Fission Density Distribution Comparison at Cycle 8 EOC

Table 3 Axial Fission Density Distribution at Cycle 8 EOC

\begin{tabular}{|c|c|c|c|}
\hline \multicolumn{5}{|c|}{ Fission density $\left(\mathbf{f i s s i o n} / \mathbf{c m}^{\mathbf{3}}\right)$} \\
\hline Axial Height $\mathbf{( \pm \mathbf { c m } )}$ & Plate 1 & Average Plate & Plate 9 \\
\hline 10.9 & $7.889 \mathrm{E}+21$ & $6.266 \mathrm{E}+21$ & $6.158 \mathrm{E}+21$ \\
\hline 12.9 & $6.956 \mathrm{E}+21$ & $5.525 \mathrm{E}+21$ & $5.430 \mathrm{E}+21$ \\
\hline 14.9 & $6.374 \mathrm{E}+21$ & $5.063 \mathrm{E}+21$ & $4.975 \mathrm{E}+21$ \\
\hline 16.9 & $5.971 \mathrm{E}+21$ & $4.742 \mathrm{E}+21$ & $4.660 \mathrm{E}+21$ \\
\hline 18.9 & $5.646 \mathrm{E}+21$ & $4.484 \mathrm{E}+21$ & $4.407 \mathrm{E}+21$ \\
\hline 20.9 & $5.389 \mathrm{E}+21$ & $4.280 \mathrm{E}+21$ & $4.206 \mathrm{E}+21$ \\
\hline 22.9 & $5.185 \mathrm{E}+21$ & $4.119 \mathrm{E}+21$ & $4.047 \mathrm{E}+21$ \\
\hline 24.9 & $5.001 \mathrm{E}+21$ & $3.973 \mathrm{E}+21$ & $3.904 \mathrm{E}+21$ \\
\hline 26.9 & $4.863 \mathrm{E}+21$ & $3.862 \mathrm{E}+21$ & $3.795 \mathrm{E}+21$ \\
\hline 28.8 & $4.754 \mathrm{E}+21$ & $3.776 \mathrm{E}+21$ & $3.711 \mathrm{E}+21$ \\
\hline 30.8 & $4.695 \mathrm{E}+21$ & $3.729 \mathrm{E}+21$ & $3.664 \mathrm{E}+21$ \\
\hline 32.8 & $4.700 \mathrm{E}+21$ & $3.733 \mathrm{E}+21$ & $3.669 \mathrm{E}+21$ \\
\hline 34.8 & $4.858 \mathrm{E}+21$ & $3.858 \mathrm{E}+21$ & $3.792 \mathrm{E}+21$ \\
\hline 36.8 & $5.441 \mathrm{E}+21$ & $4.322 \mathrm{E}+21$ & $4.247 \mathrm{E}+21$ \\
\hline
\end{tabular}

\section{Limiting Fuel Temperatures}

The thermal-hydraulic safety analysis for the NBSR has been documented in Reference 7. The tool utilized for the safety analysis is RELAP5. As described in Reference 3, the power distributions in the RELAP5 model are derived from the full-core power distributions calculated using MCNPX. The channels with hot spots and hot stripes are modeled using a conservative 
methodology to simplify the power distributions calculated with MCNPX. Nuclear hot channel factors (for example, local power peaking) are modeled but engineering hot channel factors (for example, uncertainties in fuel meat thickness) are not explicitly considered in this analysis. A summary of some relevant assumptions is included here, but full discussion may be found elsewhere [3].

In the RELAP5 model, five flow channels are used to model the six inner plenum fuel elements and eight flow channels are used to represent the twenty-four outer plenum fuel elements. It is assumed in the NBSR model that the core channel flow paths are connected in parallel and the power to each channel is determined based on the fission distribution calculated by MCNPX. Each core channel has heat structures representing the fuel plates in the lower and upper core regions. A core channel may represent multiple fuel plates lumped together as an effective plate with an effective flow channel representing the flow through the plated and un-plated regions. The RELAP5 analysis only accounts for one-dimensional heat transfer from the fuel to the coolant and no axial or lateral heat conduction in the fuel plate is modeled. A hydraulic flow channel is shown in Figure 21.

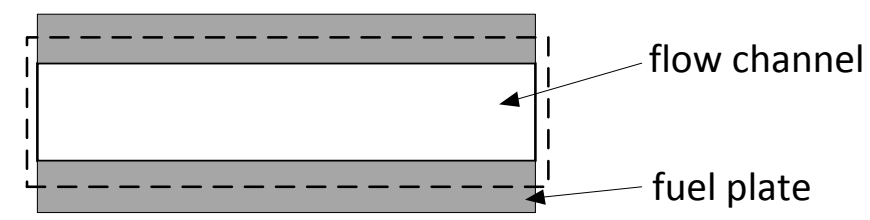

\section{Figure 21 Hydraulic Flow Channel (shown horizontally)}

The heat generated in a fuel plate is transferred to the two adjacent flow channels. In the analysis it is assumed that the power generated in the hottest plate is transferred into one common flow channel as shown in the lower diagram in Figure 22. This is conservative for two reasons. Firstly, the hottest plate, by definition, is next to a plate that is not as hot (plate A in Figure 22) and secondly, it is observed from the power distribution analysis that the hottest plate is always the outer-most plate in a fuel element. The latter means that one side of the hottest plate faces a channel that has an unfueled aluminum plate on the other side (plate B in Figure 22) and hence, has cooler water on that side. The heat flux into this cooler outside channel $q_{B}^{\prime \prime}$ is more than the average heat flux from the hottest plate and the heat flux into the hot channel $q_{A}^{\prime \prime}$ will actually be less than the average heat flux $\left(q^{\prime \prime}\right)$ from that plate. 


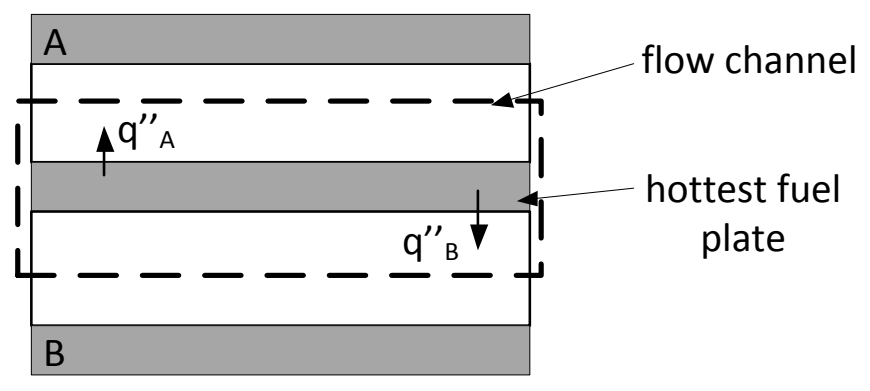

$\downarrow$ Modeling

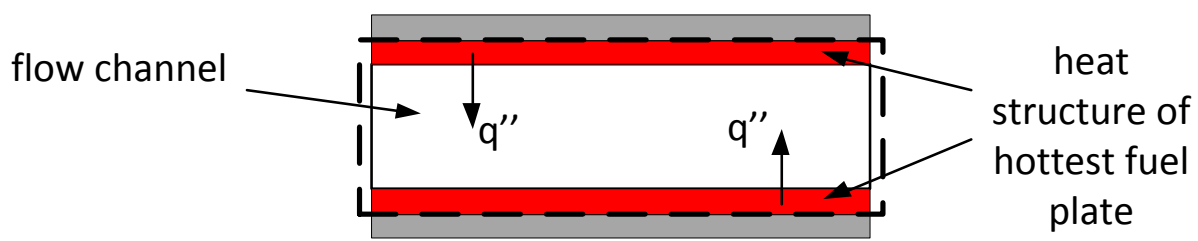

Figure 22 Heat Transfer Modeling Simplifications in a Flow Channel

The power distribution in the NBSR core is modeled using heat structures for flow channels. A FORTRAN program has been developed to read the very detailed fission information in each cell, as calculated by MCNPX. The program examines the hottest cells where the highest power is produced in the inner and outer core plenum.

The power distributions are examined along the axial cells that include the hottest cell. This is called a "fuel stripe" and represents one-third of a fuel plate. This is illustrated in Figure 23. The model is conservatively simplified by assuming that the power distribution in the hottest axial stripe is the same in the remaining two lateral stripes. This methodology is illustrated in Figure 23.

The steady state axial fuel meat centerline temperature distribution is shown in Figure 24 for the most limiting LEU core condition. Even though the methodology for obtaining the power distribution in RELAP5 is conservative, the predicted fuel meat temperatures are less than $390 \mathrm{~K}$ for all nodes. 

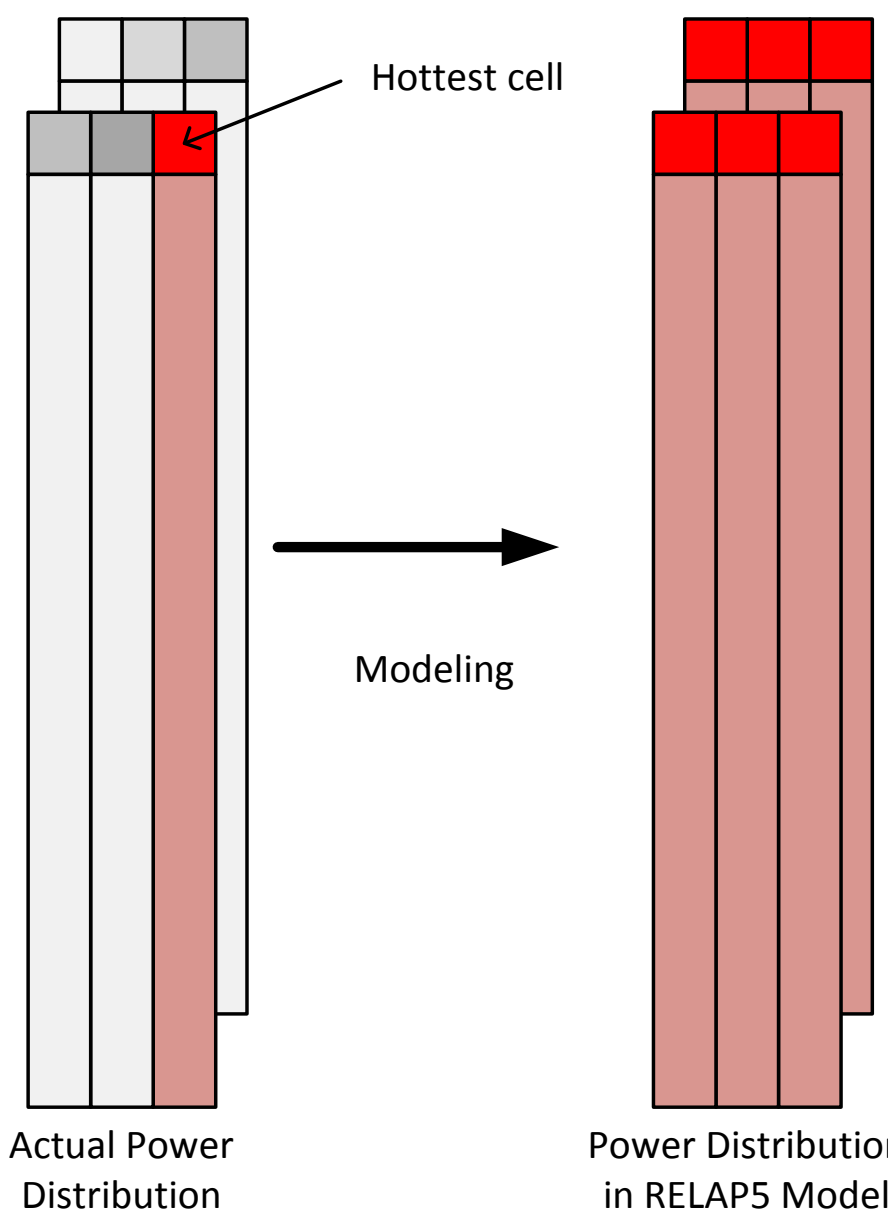

Power Distribution

in RELAP5 Model

Figure 23 Modeling of Power Distribution in the RELAP5 Input Model 


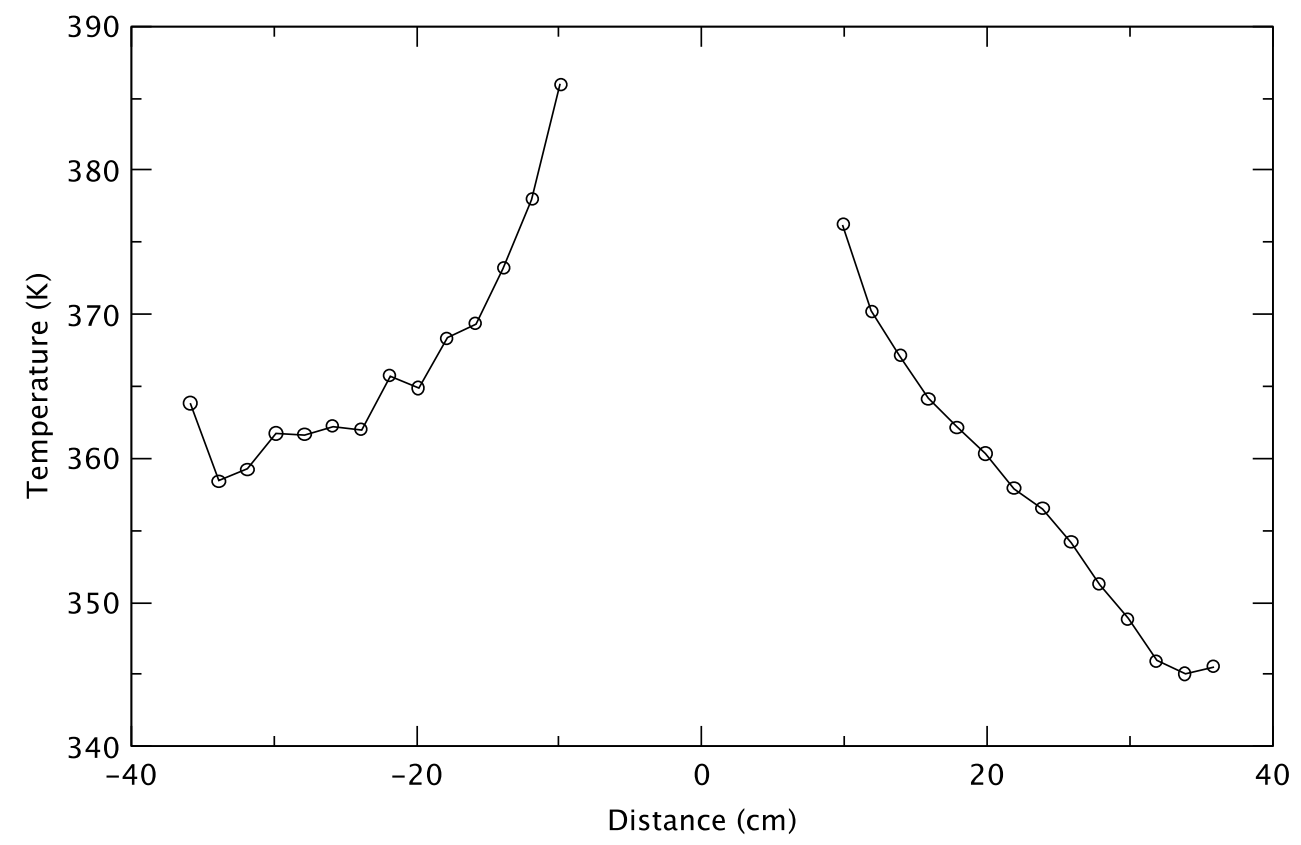

\section{Figure 24 Axial LEU Fuel Meat Centerline Temperature Distribution (Limiting Core Condition)}

\section{Summary}

This report presents a compilation of requested information relevant to the design of irradiation experiments for the LEU NBSR fuel. This report is intended to provide only the significant highlights of the LEU NBSR core design and safety analysis. An effort has been made to present best-estimate results for the most limiting LEU core conditions. The channels with hot spots and hot stripes were modeled with a methodology for simplifying the core power distributions that produces conservative results. Additional detail regarding the methods utilized in the calculations is provided in the relevant references, although the context and presentation differs from this document. A summary of some of the requested metrics is presented in Table 3.

Table 4 Values of the Requested Metrics

\begin{tabular}{|l|c|}
\hline \multicolumn{1}{|c|}{ Parameter } & Value \\
\hline Average fission rate density $\left(10^{14} \mathrm{fission} / \mathrm{cm}^{3}-\mathrm{s}\right)$ & 1.657 \\
\hline Peak fission rate density $\left(10^{14} \mathrm{fission} / \mathrm{cm}^{3}-\mathrm{s}\right)$ & 4.029 \\
\hline Average heat flux $\left(\mathrm{kW} / \mathrm{m}^{2}\right)$ & 573 \\
\hline Peak heat flux $\left(\mathrm{kW} / \mathrm{m}^{2}\right)$ & 1394 \\
\hline Average fission density $\left(10^{21} \mathrm{fission} / \mathrm{cm}^{3}\right)$ & 4.134 \\
\hline Peak fission density $\left(10^{21} \mathrm{fission} / \mathrm{cm}^{3}\right)$ & 7.888 \\
\hline Fuel meat temperature $(\mathrm{K})$ & $<390$ \\
\hline
\end{tabular}




\section{References}

[1] NIST, "Safety Analysis Report (SAR) for License Renewal for the National Institute of Standards and Technology Reactor - NBSR; NBSR-14, Rev. 4," U.S. Department of Commerce, NISTIR 7102, National Institute of Standards and Technology, 2010. Note that this is a modified version of the original NBSR-14 issued in 2004.

[2] A. L. Hanson and D. J. Diamond, "Calculation of Design Parameters for an Equilibrium LEU Core in the NBSR,” BNL Technical Report, Brookhaven National Laboratory, September 29, 2011.

[3] J-S. Baek, "Power Distribution in NBSR Core for RELAP5 Safety Analysis,” BNL Technical Report, Brookhaven National Laboratory, May 25, 2012.

[4] A. L. Hanson, N. R. Brown, and D. J. Diamond, "Effect of Shim Arm Depletion in the NBSR,” BNL Technical Report (BNL-99764-2013-IR), Brookhaven National Laboratory, February 21, 2013.

[5] N. R. Brown, A. L. Hanson, and D. J. Diamond, "Local Burn-Up Effects in the NBSR Fuel Element,” BNL Technical Report (BNL-99145-2013-IR), Brookhaven National Laboratory, January 23, 2013.

[6] A. L. Hanson, "The Maximum Burnup in an NBSR Fuel Element,” BNL Memorandum, Brookhaven National Laboratory, February 9, 2012.

[7] J-S. Baek, A. Cuadra, A. L. Hanson, L-Y. Cheng, N. R. Brown, and D.J. Diamond, "Accident Analysis for the NIST Research Reactor Before and After Fuel Conversion,” BNL Technical Report (BNL-98524-2012-IR), Brookhaven National Laboratory, September 27, 2012.

[8] E. H. Wilson, "Irradiation Conceptual Design Parameters," Electronic mail communication, Argonne National Laboratory, February 4, 2013.

[9] D.B. Pelowitz, "MCNPX Users Manual Version 2.7.0," LA-CP-11-00438, Los Alamos National Laboratory, 2011.

[10] J. M. Rowe, “Choice of Mesh Size for Hot Strips," NIST Memorandum, National Institute of Standards and Technology, May 15, 2008.

[11] L-Y. Cheng, "Heat Conduction in a NBSR Fuel Plate - Effect on Wall Heat Flux," BNL Memorandum, Brookhaven National Laboratory, April 6, 2010. 